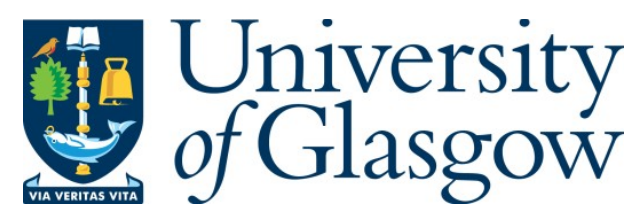

Jacobsson, P. (2019) Challenges and prospects for building radiocarbon chronologies of the earlier Holocene of the Levant. Levant, 51(1), pp. 6-25.

(doi: $10.1080 / 00758914.2019 .1689747)$

There may be differences between this version and the published version. You are advised to consult the publisher's version if you wish to cite from it.

http://eprints.gla.ac.uk/203904/

Deposited on: 21 November 2019

Enlighten - Research publications by members of the University of Glasgow http://eprints.gla.ac.uk 


\section{Challenges and prospects for building radiocarbon chronologies of the earlier Holocene of the Levant.}

\section{Piotr Jacobsson}

This paper explores the challenges of building radiocarbon chronologies of the earlier Holocene of south-west Asia. The analysis consists of a technical and a taphonomic review of a selection of the published ${ }^{14} \mathrm{C}$ record followed by a modelling study of a subsection of that data. This sketches the kinds of chronological syntheses we can hope to construct, given the nature of the sites in the region. The key observation from the review of individual radiocarbon determinations is that reliable radiocarbon dating contexts are very limited. This is due to taphonomic ambiguity associated with charred plant remains and the persisting difficulties in dating skeletal remains from south-west Asia. The modelling study highlights the challenges of tracing events such as site onset and abandonment on complex, long-lived sites and the large extent of chronological ambiguity stemming to a large extent from the taphonomic challenges. Many of these issues might be resolved through new ${ }^{14} \mathrm{C}$ extraction techniques, the ongoing improvement of excavation methods, as well as rethinking chronological syntheses with a greater focus on relationships between specific contexts.

Keywords: radiocarbon dating; radiocarbon sampling; Bayesian chronological modelling; Pre-Pottery Neolithic

\section{Introduction}

The past decade has witnessed the rise of high-precision chronologies of Neolithic communities throughout Europe (Whittle 2018; Whittle et al. 2011). These projects demonstrated the importance of chronological detail to understanding the dynamics of developments on the scales of an individual village, or a specific area. This is of major interest to south-west Asian earlier Holocene, given the ongoing recognition of the 
relevance of such localized studies to the construction of meaningful prehistories (e.g. Asouti 2006; Barzilai 2010; Borrell and Mollist 2014; Koutrafouri 2008). Furthermore, the networked nature of many of the earlier Holocene communities of south-west Asia (see Ibáñez et al. 2018) places a unique premium on high-precision radiocarbon chronologies, as they alone provide the means of assessing the speed of new developments dispersed over these interaction zones. The importance of being able to attain a sufficient radiocarbon resolution becomes apparent when discussing the major culture-historical transitions in the region, such as the timing of the onset of the PPNB between northern and southern Levant (Edwards 2016), and may be essential to resolving the origin of such changes. Hence, if we want to describe the cultural nuance of the earlier Holocene well, we need clear, unambiguous chronologies.

This paper explores the current state of published radiocarbon chronologies, ways of thinking about them and possible means of improving upon them in the context of the earlier Holocene of the Levant (including Cyprus). The earlier Holocene is taken here to span the period from the end of the Younger Dryas around 9,500 cal BC to the end of the $7^{\text {th }}$ millennium transformations around 6,000 cal BC. Following a brief summary of the basics of radiocarbon dating and chronology construction, the paper consists of two main sections:

- The first section, Chronological hygiene, discusses the results of a technical and contextual assessment of 547 published radiocarbon determinations from 21 sites. This assessment covers both the contextual and the technical reliability of the individual samples. The section summarizes the criteria and outcomes of the assessment. This is followed by a discussion of the results for the two major 
types of sample material (charred plant remains and skeletal remains) alongside possible directions for future improvement.

- Modelling, syntheses and contexts, the second major section summarizes the results of site-level chronological models from 13 of the 21 sites covered in the section on chronological hygiene. The aim here is to identify the range of questions that can be answered given the nature of the published radiocarbon record, and also to develop an understanding of how precise these answers are at the time of writing. The key observation here is that the nature of the questions that can be asked of the radiocarbon record implies a move towards more granular, feature-oriented syntheses that might provide a more suitable basis for chronology building. The section concludes with two examples of how this may play out in practice. These case studies also demonstrate how the technical improvements covered in the section on Chronological hygiene will improve actual archaeological results.

\section{Radiocarbon dating, calibration, modelling: implications for sampling and interpretation}

Natural ${ }^{14} \mathrm{C}$, also known as radiocarbon, is produced in the upper atmosphere in interactions between nitrogen and neutrons created as a consequence of high-energy cosmic particles colliding with other atmospheric particles. Radiocarbon has the same chemical properties as any other carbon atom and therefore permeates the biosphere - including past and present 
human societies. At the same time, however, it is also subject to decay at a constant rate. Thuis, based on the concentration of ${ }^{14} \mathrm{C}$ in the sample, we can estimate how much time elapsed between the present and the time when the sample stopped exchanging carbon with its environment (which in most cases implies death).

As ${ }^{14} \mathrm{C}$ production and circulation varies with time, radiocarbon age determinations need to be calibrated before they become meaningful for archaeological research (see Beer et al. 2012 for an in-depth treatment of all aspects of radiocarbon from production to circulation). The accepted calibration procedure is to use ratified curves based on measurements of radiocarbon concentration in known-age samples. IntCal13 (Reimer et al. 2013 ) is the current ratified curve, although a new calibration curve is set for release in 2020.

Because of the shape of the calibration curve, the most meaningful algorithm for individual calibrations produces the entire probability distribution of a given date (Stuiver and Reimer 1986; van der Plicht 1993; Weninger et al. 2015). This means that discussing calibrated radiocarbon dates in terms of point values and their standard errors (eg. $7400 \pm 75$ cal BC) is often meaningless and it is more useful to speak in terms of date ranges (eg. 76007350 cal BC at $95.4 \%$ probability). In statistical parlance, such ranges are referred to as Highest Posterior Density Areas, or HPD Areas (Hoff 2009).

While calibrated radiocarbon date ranges provide the date when the sample stopped exchanging carbon, it is very rare that this event is of direct interest to the archaeologist. In the context of earlier Holocene research in the Levant, these exceptional circumstances occur for example when dating when early domestic-type cereals with a view to date early 
cultivation (Moore 1992). However, in the majority of instances, we are interested in questions relating to when particular cultural developments took place, or how fast these changes occurred. Such questions often lack a direct relationship to the information on the physiological death of plants and animals at archaeological sites and hence some form of inference and synthesis is unavoidable. Perhaps the most popular way of addressing these issues is through a Bayesian framework developed by the Sheffield group (Buck et al. 1996), yet alternative frameworks exist (Lanos and Philippe 2015; Weninger et al. 1986-2016). For a recent detailed discussion of what the Bayesian framework entail, refer to $\mathrm{xx}: \mathrm{xx}$ or $\mathrm{xx}: \mathrm{xx}$.

The basic premises of radiocarbon dating, calibration and modelling are the foundation for assessing archaeological ${ }^{14} \mathrm{C}$ chronologies. Perhaps first and most important of these is the notion that the radiocarbon determinations must carry some archaeological meaning. Almost anything on an archaeological site can be submitted for ${ }^{14} \mathrm{C}$ analyses, but only a very small fraction of materials will produce meaningful results. Such samples must fulfil two requirements:

(1) The carbon submitted for ${ }^{14} \mathrm{C}$ measurement must be relevant to the question at hand. During the course of deposition, a potential sample will take on carbon from multiple sources, ranging from mobile products of plant decay, to carbonates introduced through movement of water within the site matrix. Hence, only those samples in which we can isolate the original carbon through chemical pre-treatment are useful.

(2) We need to understand the relationship between the sample and its context. This is covered under the concept of a dating assemblage (Boaretto 2015: 209), whereby 
the dating assemblage of a primary context consists of ${ }^{14} \mathrm{C}$-datable material and supporting evidence tying this material to the event of context formation In some cases, such as articulated skeletal remains, demonstrating such a relationship is straightforward: the bones would have been deposited not long after death and so the radiocarbon determination would date the formation of the context in question. In case of a hearth the pathway of the charcoal could have been more complex with the sample being collected from an assemblage of deadwood, or from an old building. In cases of isolated fragments of bone and charred plant remains, it might be impossible to link the radiocarbon determinations to archaeological events. Dating charcoal also brings some additional concerns. Much of the carbon in woody plants is dead on formation. This leads to concerns over the "old wood effect" (Schiffer 1986), a situation in which the calibrated date range marks formation of woody material that could have pre-dated the cutting of the tree in question and the formation of archaeological contexts in which it was discovered.

Moreover, the dated contexts must relate to the archaeological questions asked. For example, we want to know when a specific structure was built. If the contexts related to the event are not sampled, or suitable materials for ${ }^{14} \mathrm{C}$ dating are lacking, the question might be unanswerable unless a reasonable inference can be carried out based on stratigraphic relationships to other, datable, features. 


\section{Chronological hygiene of the legacy ${ }^{14} \mathrm{C}$ data from the earlier Holocene of the Levant and the range of datable contexts}

Considerations of the previous section highlight the importance of both technical and contextual security of radiocarbon dates. These factors depend to an extent on local conditions, whether they are related to the diagenesis of sample material, or to the past cultural and ecological choices affecting the composition and distribution of ${ }^{14} \mathrm{C}$-datable material in archaeological sites. Hence, any broad time period and geographic area will have its own unique challenges as far as building radiocarbon chronologies is concerned, and the identification of these challenges is the first step to their alleviation. This can be achieved by an assessment of the chronological hygiene of published (legacy) radiocarbon data. This paper is based on such an assessment of radiocarbon assemblages from 21 earlier Holocene sites (Supplementary Tables S1-S21). These include 13 sites from Cyprus, which covers all earlier Holocene deposits that were excavated and ${ }^{14} \mathrm{C}$ dated prior to 2015 , as well as eight sites from south-west Asian mainland. The selection of mainland sites was guided by the presence of technical and conceptual features that would enrich our understanding of radiocarbon dating of earlier Holocene deposits in the Levant in general. One further criterion for the selection of mainland sites was the presence of a sufficient publication record to enable an informed assessment of a given site's chronology. Hence, sites with small radiocarbon assemblages, such as Ba'ja (Gebel and Kinzel 2007), or others with large assemblages but still in preliminary stages of publication, such as Motza (Khalaily et al. 2007), are omitted. The two largest ${ }^{14} \mathrm{C}$ assemblages from the earlier Holocene of southwest Asia, Çatalhöyük (Bayliss et al. 2015; Marciniak et al. 2015) and Tell Sabi Abyad (van 
der Plicht et al. 2011; Plug et al. 2014), are also omitted. Both of these sites are subject to intensive further chronological studies and their chronologies are complex enough to demand papers of their own.

\section{Chronological hygiene: methodology}

The importance of chronological hygiene whenever dealing with legacy radiocarbon data is well understood (Fitzpatrick 2006; Spriggs 1989; Taché and Hart 2013). Therefore, the first step of this study was to collate technical and contextual information on the individual samples to evaluate their overall reliability. The assessment itself is split into two parts: technical and contextual (Table 1). The technical assessment focuses on the pre-treatment and measurement of the samples studied. An example of a sample that failed the technical assessment is determination P-2551 sampled Kalavassos-Tenta, Cyprus, which was measured by the now closed University of Pennsylvania Radiocarbon Laboratory. P-2551 lacked an alkali wash during pre-treatment and as a result the charred plant material constituting the sample was not isolated from the by-products of plant decay present in the surrounding soil matrix. Divergences in dates between samples from contemporaneous contexts that were pre-treated both with and without an alkali step prove that this can be an issue (Figure 1; Fishman and Lawn 1978: 218). One aspect that the technical assessment did not cover was measurement precision, as low measurement precision in its own right does not imply a technical fault with radiocarbon determination. 
Contextual assessment scrutinized the relationship between the samples that passed the technical assessment and their contexts. For example, lentils dated as sample KN-4879 derive from a seed store fire at 'Ain Ghazal are a reliable sample: they would have been harvested not long before the burning event and, as their relationship to this context is unambiguous, they constitute a reliable dating assemblage. In an ideal world, all radiocarbon samples would come from such or similar contexts that are proven to be primary dating assemblages. However, the amount of material passing the assessment under such criteria would be too limited to form the basis for any future recommendations. Hence, two different standards were introduced for the contextual assessment. The stricter standard only accepted samples such as KN-4879: short-lived samples from secure contexts with a clear taphonomic path. The relaxed standard was much broader, allowing for some degree of uncertainty in taphonomic paths and ignoring risks of old wood effects. These are the kinds of samples that can be modelled with guarded confidence by either being treated as terminae post quos, or through outlier modelling (Bronk Ramsey 2009a). Results based on the relaxed assessment may guide future research and, in time, new data should remove the need to rely on them.

\section{Assessment outcomes}

Altogether 547 samples were studied (Figure 2; Table 2). Three hundred and seventy two samples (68.0\%) pass the technical assessment. Under the relaxed criteria, 227 samples pass the contextual assessment ( $44.2 \%$ of the total), but only 22 pass the strict criteria $(4.2 \%$ of the total). The sub-sections that follow discuss the assessment results and implications for 
bone and charcoal, the dominant sources of material for ${ }^{14} \mathrm{C}$ dating. The materials grouped as "other" are not discussed further due to their limited occurrence in undisturbed archaeological contexts, or due to very experimental nature of sample pre-treatment protocols precluding hope of their routine dating in the near future.

\section{Charred plant remains}

Levantine earlier Holocene radiocarbon assemblages are dominated by charcoal and charred plant remains. These samples are straightforward from a technical point of view, as contaminating materials can be removed using the routine acid-alkali-acid technique (e.g. Brock et al. 2010). This is reflected in the pass rates of the technical assessment, with 357 of the 398 charcoal and charred plant remain samples clearing the criteria. Of the 41 charred plant remain samples that fail the technical assessment, 14 are the early Tell es-Sultan determinations carried out by the London Geochronological Laboratory, and the Groningen laboratory. These samples are rejected because of the lack of standardization in the first decade of radiocarbon dating. Further 19 charred plant remain samples are rejected due to insufficient pre-treatment.

The remaining eight charred plant remain samples rejected in the technical assessment suffer from offsets indicative of unknown technical issues during sample pretreatment and measurement. This category also includes samples that might be subject to subtle diagenetic effects that might not be possible to tackle by the routine acid-alkali-acid protocol. This is suggested by the presence of divergent dates in the charred seed concentrations from Structure 700 at Yiftahel (Garfinkel et al. 2012), or in the large LPPNB 
building in 'Ain Ghazal North Field (Rollefson 1998: 8). In both cases there is little ambiguity as to the nature or security of the contexts: they are mass storage deposits containing tens of thousands of charred seeds and the divergence emerges between the seeds from these contexts. Hence, it is more plausible that an unknown technical factor might be responsible for the deflection towards the older radiocarbon ages seen within some samples from these assemblages. Nevertheless, the basis for the emergence of such offsets remains unclear. One potential identified technical problem with acid-alkali-acid pre-treated charred plant remains comes from Motza, where during pre-screening Yizhaq et al. (2005) detected clays that survived the routine acid-alkali-acid treatment. However, as these samples were not ${ }^{14} \mathrm{C}$ dated and compared to material from the same secured contexts, it is very difficult to argue that there is a link between clay survival and an offset towards older ages of the kind identified in the charred seed stores of Yiftahel and 'Ain Ghazal. It is also essential to remember that these are, to date, the only two cases where acid-alkali-acid pre-treated charred plant remain samples produced results that are anomalous and that can be tracked to a technical issue. On the whole, the pre-treatment regime for charred plant remains from the Holocene and much of the final Pleistocene is robust.

The true chronological weakness of charred plant remains is taphonomic ambiguity. Only 23 of the 398 determinations on charred plant remains pass the strict contextual assessment, and even under the relaxed assessment, the rejection rate is still high (120 samples of 398 are rejected). As stated above, unless the sample derives from a secure, unambiguous context, such as a hearth, or a structural element, defining its relationship to the feature of interest is laden with risk. One example of this are the domestic-type cereals 
recovered from Abu Hureyra, where multiple trenches were excavated across a mound that contained both final Pleistocene and earlier Holcoene deposits. To the surprise of the excavators, domestic type cereals were recovered from the final Pleistocene deposits (Moore et al. 2000). However, AMS dating made it clear that at least some of the seeds in question were grown in the earlier Holocene and that they were invasive to the final Pleistocene contexts. The reverse scenario, where old residual material becomes incorporated into archaeological deposits is also possible (see eg. Scirè Calabrisotto et al. 2017; Wicks et al. 2016).

Another set of issues, specific to charcoal and building materials, are the old wood and the "old house" effects (Faust and Sapir 2018). Some of the timber species encountered throughout the Levant can be long-lived, so the charcoal produced in burning them provides dates that reflect the growth period of the tree and not the formation of the archaeological context. Furthermore, building materials can be re-used from structure to structure. This includes not only timber, but also short-lived materials used as temper for mud plaster in situations where old mud is recycled. The magnitude of these kinds of effects is clear at the PPNA Wadi Feynan 16, where an unambiguous old wood effect could be observed in the charcoal assemblage, alongside a high rate of plausible residual material among the shortlived charred plant remains (Wicks et al. 2016).

Whenever discussing taphonomic issues and old wood effects it is useful to remember that the unambiguous cases are least problematic. Both at Abu Hureyra (Moore et al. 2000), or Wadi Feynan 16 (Wicks et al. 2016) the magnitude of dating offsets is counted in centuries or millennia, so the issues can be recognized and addressed. However, 
it is conceivable that on many sites such offsets are much smaller and so might introduce errors that remain undetected. Hence, while charred plant remains are a reliable sample type from a technical point of view, archaeological contexts where we can be sure that the date of the charred plant material also dates the formation of the context can be rare.

Nevertheless, charred plant remains are the workhorse of earlier Holocene chronologies in the Levant and are set to remain in this position in the years ahead. As such, if we want to be able to date a broader range of contexts to a level implied in the strict chronological assessment, we need to find ways of dealing with taphonomic ambiguity.

\section{Charred plant remain identification and anthracology}

Plant identification prior to dating is the first major step towards improving the chronological reliability of charred plant remains. While identification in itself is not be enough to tackle all taphonomic issues, it is sufficient to avoid sampling long-lived species as far as possible and adjust for old wood effects with outlier models where applicable. Where resources and personnel permit, further inspection of the charred plant remains assemblages has the potential of distinguishing samples that were cut from ones that suffered substantial microbial and fungal attack (Austin 2007), hence improving our understanding of sample taphonomy and providing the basis for mitigating action.

\section{Microarchaeological techniques}

Another approach is to employ microarchaeological techniques to identify secure contexts beyond those apparent to the naked eye. This is possible because such techniques, ranging from microstratigraphic analysis to chemical characterization of archaeological layers, can 
confirm not only whether a given context is intact, but also provide some information on how it formed (e.g. Asscher et al. 2015a, 2015b; Toffolo et al. 2012). Hence, while an isolated charred seed from a pit feature does not constitute a most reliable sample, as it might be either intrusive, or residual, microarchaeological methods can prove contextual integrity, thus removing the risk of the material being intrusive, and demonstrate whether it formed in a thermal event, thus tying the charred seed to context formation.

\section{Quantifying ethnoarchaeological observations}

Several ethnoarchaeological projects (eg. Gur-Arieh et al. 2013; Jenkins et al. 2017) succeeded in developing a fundamental understanding of how organic materials circulate in traditional communities using building materials analogous to those found in earlier Holocene contexts in the Levant. If quantified, such observations might provide a basis for a more refined approach to dealing with samples that may suffer old wood effects, or come from material that was recycled throughout the history of the site. This is important, as even with universal identification of plant remains and with widespread adoption of microarchaeological techniques, there will be sites without adequate contexts and dating material associated with key features of interest. In these situations, the ability to quantify the taphonomic uncertainties might prove essential to meaningful interpretation of the radiocarbon record. 


\section{Skeletal remains}

None of the taphonomic concerns that affect the dating of charred plant remains apply to dating articulated skeletal remains. This is because we can be certain that skeletal remains found in articulation, such as limbs of animals in midden contexts, or human burials (at least where there are no grounds to suspect redeposition of entire bodies using coffins or similar containers), have been deposited in their resting location not long after death. Hence, human and animal bones form the basis of many large radiocarbon dating programmes (Bayliss et al. 2015; Jakucs et al. 2016; Marciniak et al. 2015; Whittle et al. 2011).

However, in the context of the earlier Holocene of the Levant dating archaeological bone is difficult. This is reflected in only 11 of the 97 bone samples passing the technical assessment. The issue has its roots in the preservation of bone collagen. As collagen is based on long carbon chains that cannot exchange atoms with their surroundings under normal conditions without breaking, any unaltered collagen extracted from an archaeological bone will provide a good ${ }^{14} \mathrm{C}$ dating sample (Dobberstein et al. 2009; Longin 1971). However, collagen preservation conditions are poor throughout the Levant (Weiner and Bar-Yosef 1990) extraction of this preferred sample fraction is often impossible, although some of the more recent attempts proved to be successful (Barzilai et al. 2017; Garrard et al. 2018; Salamon et al. 2010). Nevertheless, where success rates are reported, it is clear that collagen extraction is far from routine. For example, at El Wad terrace only five of the 34

screened bones yielded material satisfactory for ${ }^{14} \mathrm{C}$ dating (Weinstein-Evron et al. 2012). These low success rates mean that there are instances where key features, such as the elevated status burial at Ba'ja (Benz et al. 2019), have to be dated through indirect 
associations, or samples that come with all the taphonomic concerns of charred plant remains. The alternative to dating collagen, dating the inorganic bioapatite is viable only in very specific circumstances (Zazzo and Saliège 2011; Zazzo et al. 2012). As such, dating archaeological bone from the earlier Holocene of the Levant will have to be based on technical improvements.

\section{Widespread screening}

While the vast majority of skeletal remains from the Levant yields either too little collagen for analysis or none at all, there are isolated instances of successful bone dating even beyond caves and cave-related context (e.g. Plug et al. 2014). Hence, it is worth submitting skeletal material to a research laboratory experienced in dating bone from arid environments, even if the odds of success are low.

\section{Single amino acid dating}

In instances where some collagen is preserved, but not enough for a reliable date, it is often possible to extract specific constituent components of protein, such as the amino-acid hydroxyproline, that are known with high certainty to be autochthonous to the bone (Devièse et al. 2017; Marom et al. 2012; McCullagh et al. 2010). While these methods are still far from routine, recent research in Palaeolithic archaeology demonstrates that they can be used on a broad scale (eg. Reynolds et al. 2017; Nalawade-Chavan et al. 2014). 
Non-collagenous proteins and other acid-soluble organics

Single amino acid dating as practiced today focuses on cases where some collagen survives. On many Levantine sites, even this might not be the case for all samples of interest. One way to overcome this issue might be the development of techniques based on extracting either broken down fragments of collagen, or non-collagenous proteins (NCPs) from the acid used to demineralize the bone. That such proteins exist and can be identified as such has been shown by Grupe (1995) for a bone from a sandy burial in Egypt, and a more recent project succeeded in re-assembling protein from the acidic solution from Levantine bones (Goldenberg et al. 2017). These techniques are experimental and very difficult to implement (for challenges of NCP isolation and extraction see Weiner 2010: 122-3), making them unsuitable for many archaeological applications. Nevertheless, the NCP osteocalcin has been isolated and has produced consistent radiocarbon results (Ajie et al. 1992). The past decade also witnessed the development of chromatographic approaches to NCP characterization and discovery (Cleland and Vashishth 2015). Given the importance of articulated human and animal remains to chronology-building, exploring these experimental avenues might prove essential in the earlier Holocene of the Levant.

\section{Chronological hygiene summary: too few good contexts}

The above assessment indicates a shortage of reliable contexts, or to be more specific, primary dating assemblages for radiocarbon dating. This is driven by the limited range of archaeological features that can be dated without concerns regarding their contextual integrity. The issue would be far more limited had it been possible to date archaeological 
bone on a more frequent basis in the Levant, as articulated skeletal remains testify to a high degree of contextual integrity. Furthermore, developments in dating other kinds of archaeological materials, such as lime plaster, or, on sites where microarchaeological techniques have been employed, phytoliths from coherent layers, can further extend the range of viable dating assemblages (Boaretto 2009: 277-8; 2015). However, this will not be possible until new sample pre-treatment methods are developed to the point where they can be used on a routine basis. Until then, our ability to improve the chronological record of the earlier Holocene in the Levant rests upon charred plant remains, so any immediate progress will have to rely on attention to contextual security and improving our understanding of taphonomy, through more attentive traditional excavation and application of microarchaeological techniques.

\section{Modelling, syntheses and contexts.}

So far, this paper discussed the overall quality of the legacy radiocarbon record for the earlier Holocene of the Levant, as well as potential ways of improving it. This is essential to any considerations of chronological refinement, but does not address the central question of what chronology contributes to archaeological interpretation. That latter question hinges on the range of deposits present and thus the nature of sites throughout the region and period of interest: unless deposits necessary to answer a given kind of question can be found with sufficient frequency, those questions become themselves unaskable. For example, if we want to study settlement abandonment pattern in an area through time 
using radiocarbon dating, we must have the capacity to date final activity evidence at a sufficient number of these settlements. Furthermore, for the answers to be meaningful they must display a degree of precision that allows for making new inferences. In terms of the example of studying settlement abandonment patterns, if the modelled precision of the abandonment events is lower than what can be inferred from material culture, then the radiocarbon study cannot provide any new insights.

This section explores what range of archaeological questions can be asked from the earlier Holcoene radiocarbon record of the Levant and what kind of chronological resolution can be obtained with regards to these questions. Key here is understanding what questions are meaningful. Although the algorithms of OxCal perform best when a start and an end Boundary(); parameter are present, this does not mean that these parameters have direct archaeological meaning. Hence, to understand how the nature of the archaeological record affects our chronological syntheses, we need to explore what range of questions are viable to ask and, at least for the purposes of understanding the potential of our current published ${ }^{14} \mathrm{C}$ record, obtain an estimate of how precise the answers can be. This is achieved through modelling the date estimates of events taking place at, or, where viable, the activity duration at the sites discussed in the previous section. The resultant evidence makes it possible to probe the range of viable chronological questions and the precision with which they can be answered as of the time of writing. 


\section{Modelling summary}

Chronological models were constructed for 13 sites (Figures 3-4; Table 3; Supplementary Figures S1-S26; Supplementary material: model scripts S1-S13). This number is high as a proportion of the 21 sites studied, as all but one mainland sites were selected for the study based on their capacity to produce meaningful chronological models. All modelling was carried out in OxCal 4.2 (Bronk Ramsey 2009b) using the IntCal13 calibration curve (Reimer et al. 2013). Outlier models (Bronk Ramsey 2009a), were used in 10 of the 13 models constructed, to address the taphonomic uncertainties associated with dating wood charcoal that makes up $74.98 \%$ of the dataset.

Across the 13 sites, 37 meaningful questions were identified:

- $\quad$ One concerned with the onset of archaeological activity at a site;

- $\quad$ None concerned with the end of archaeological activity at a site;

- $\quad$ Sixteen concerned with particular features of interest;

- $\quad$ Fifteen concerned with in-site stratigraphic or cultural transitions;

- $\quad$ Five concerned with the duration of a particular spate of activity.

The majority of the dated contexts are more informative about the chronology of events happening within the time of activity at a given site, than of the determination of the onsets and terminations of the occupations at these sites. The 68.2\% HPD across all parameters range from 30 to 370 cal years, with a median of 175 cal years. The $95.4 \%$ HPD areas of these parameters range from 75 to 825 cal years, with a median of 360 cal years, so almost half of the parameters of interest are estimated to ranges broader than $400 \mathrm{cal}$ years. 
Two immediate observations stem from the modelling study:

1. The models summarized above often lack precision. This is to be expected, as many of the legacy determinations were commissioned when measurement uncertainties exceeded \pm 50 uncalibrated ${ }^{14} \mathrm{C}$ years, which translates to very long calibrated date ranges and thus low model precision. Nevertheless, heavy reliance on outlier models and other means of negotiating the taphonomic challenges posed by charcoal and other charred plant remains also contributes to this lack of model precision. This confirms doubts that the current set of legacy

${ }^{14} \mathrm{C}$ data can provide chronological resolution sufficient to meet the demands of contemporary research on the earlier Holocene of the Levant (Ibáñez 2018: 245).

2. While questions regarding onsets and terminations of activity on archaeological sites remain elusive, we appear to be in a good position to trace intra-site transition and dates for particular features of interest.

While the former of these issues can only be resolved through increasing volume, precision and contextual reliability of the radiocarbon determinations themselves (thus bringing us back to the considerations of the preceding section), the latter requires a more in-depth exploration.

\section{Onsets and terminations of archaeological activity: implications for chronological} synthesis.

The majority of known and excavated Levantine earlier Holocene archaeological sites were occupied for centuries, some for millennia. However, archaeological exploration of these sites is often limited to small, hand-excavated trenches, and thus the extent of spatial 
coverage over any given archaeological site is minute. In such cases, it is difficult to know whether the basal deposits uncovered mark the beginning of activity at a site. There is no way of knowing on a 10 hectare mound whether deepest the archaeological deposits found in a single $2 \mathrm{~m}$ by $5 \mathrm{~m}$ trench are the earliest at the site, or whether remnants of a 500 years' worth of older deposits might be present $20 \mathrm{~m}$ into the section. In a similar fashion, re-use and erosion means that the final stages of activity at any given archaeological site might be either absent altogether, or not to be found in a small exposure. Hence, except for a few small sites that underwent near complete excavation, we are often faced with an unquantifiable uncertainty of the chronological spacing of the deposits we date from the onset or end of earlier Holocene archaeological activity at a given site. This becomes apparent when we consider sites where a different siting of trenches, or neglect of some aspects of the stratigraphic record, could have led to very different expectations about onset, phasing, and termination. Two examples from Cyprus exemplify this issue.

The first case study is Khirokitia-Vounoi, Cyprus, a village dating to at least the $7^{\text {th }}$ millennium cal $\mathrm{BC}$ and divided into two sectors, East and West, by an intra-settlement wall (Structure 100 and its antecedents) (Le Brun and Daune-Le Brun 2009; Le Brun 1984; 1989; 1994). Extensive excavation demonstrated three major phases of construction in the West sector and at least seven such phases in the East sector. Based on stratigraphic relationships around the intra-settlement wall (Structure 100), the excavators were able to that at least six layers of building were laid down in the East sector before first buildings were erected in the West sector (Le Brun 1994: Ch. 1; Le Brun and Daune-Le Brun 2009). Had the excavators placed trenches in the West sector and dated deposits associated with the earliest buildings 
there, the resulting model, while accurate for the onset of activity in the West sector, would have missed the onset of activity at the site as a whole by hundreds of years.

The second example is Parrekklisha-Shillourokambos, Cyprus, where, as at Khirokitia, there are two main excavated area: North and Central. The site itself is known for its negative features, such as Well 23, a deposit of human and animal remains attributed to the LPPNB (Guillaine et al. 2011). The infill of all of the negative features from Shillourokambos dated so far derive from either the late $9^{\text {th }}$ or early-mid $8^{\text {th }}$ millennium cal BC, which coincides with the Ancienne and Moyenne phases of the site. Nevertheless, there is a continuing activity at Shillourokambos marked by some of the lithic material recovered and a small set of features, including a small, thick-walled, round structure that constitute the Recente phase. However, deposits dating to the Moyenne and Recente phases appear to be absent from the Northern excavation zone (Guillaine et al. 2011: 584). Hence, again, had the trenches at Shiollourokambos been placed in a different way, the data would suggest that activity at the site ended with the end of the Ancienne phase phase, which would be an under-estimation.

Most excavators working in the Levant are aware of the limitations of their record in terms of finding earliest (or latest) deposits at their sites and, hence, much of the site level analysis is proof to the kinds of concerns discussed above. This was also a secondary concern for earlier synthetic chronological studies that only aimed to place main cultural or typological entities in time (Gopher 1994; Henry and Servello 1974; Aurenche et al. 2001). However, as the level of chronological detail we require to answer new research questions increases, the difficulty inherent in defining site onsets, terminations and activity hiatuses 
begins to erode the conclusivity of aggregate chronological studies. The issue is, to a large extent, theoretical: when working at macro-scales it is difficult not to fall back on entire sites as basic analytic units of study. However, as we often do not have the evidence to comprehend the entirety of a site's history, this means that we do not understand the basic analytic units, and the foundations of resultant syntheses is not as convincing as they could be.

A good example of how these limitations can play out is provided by Borrell et al. (2015). This paper explored how rapid climate change (RCC) around 8,200 cal BC could be a decisive factor in the transformation of hunter-gatherer-cultivators into agro-pastoralists, alongise a transformation in the overall settlement pattern. The authors base this suggestion on the major gap in the regional radiocarbon record based on 20 sites, which coincides with the period around 8,200 cal BC. Yet, setting aside the methodological problems inherent in using summed probability distributions (Bronk Ramsey 2017; Contreras and Meadows 2014), there are two ways this conclusion can be brought into question. On one level, there are different ways that the evidence from some of the sites referred to by Borrell et al. (2015) can be interpreted. For example the paper presents only two dates from 'Abr 3, which is not enough to characterize the duration of activity at the site. Likewise, the dating of the final stages of MPPNB activity at some of the sites hinges on very limited evidence. At Mureybet there are only three determinations from the most recent Phase IVB, two of them perhaps at odds with the site stratigraphy (Evin and Stordeur 2008: Tab. 2) and at Göbekli Tepe there is only one determination from the MPPNB Layer II that can only act as a tentative TAQ (Dietrich et al. 2013: 37). Hence, it is very easy to argue 
that the estimates presented by Borrell et al. (2015) might not be a good reflection of when activity at some of the sites discussed came to a close. Furthermore, while a number of sites might have their apparent terminations close to a climatic event, this alone can only suggest, not prove, a causal relationship between the RCC event and the settlement and subsistence transformations. To demonstrate such causal relationship we would need to date contexts from within the sites themselves that would date to the RCC event and check whether the burial, dietary, architectural, or other records imply evidence of a sudden resource stress.

The criticism above does not detract from the most important contribution that Borrel and colleagues make: highlighting the possibility of an RCC impact on a key transition in subsistence and settlement patterns. However, as long as correlation does not imply causation, more in-depth research is necessary to confirm the observed possible links. Numerous aggregate studies similar to that by Borrell et al. (Flohr et al. 2016, Fort et al. 2012; Maher et al. 2011, Pinhasi et al. 2005) have scoured the Final Pleistocene and the Earlier Holocene for evidence of correlation, so that the range of new things we can learn this way is limited and gaining new knowledge requires going into ever greater detail. This entails broadeining the range of datable contexts discussed in the preceeding section, but also call for alternative approaches to chronological synthesis. 


\section{Thinking through contexts}

The challenges caused by using entire sites as analytic units in building chronological syntheses can be avoided by using smaller, more comprehensible, analytic units. Specific archaeological features fit this requirement well. As they emerge either from specific processes or events, thinking in terms of specific features gives us chronological information free from the ambiguities associated with trying to think of chronological synthesis in terms of entire sites, or even site "levels". These ambigutiies emerge not only due to the onset/termination issues outlined above, but also due to the occasional ambiguity of associating stratigraphy over multiple trenches, as well as chronological dilution that comes from the longevity of many stratigraphic layers. This has been, for example, pointed out by Dietrich et al. (2013: 40-41) in their discussion of potential chronological variability between the different enclosures at Göbekli Tepe Level III, where the different monumental enclosures might have been built years apart, with Enclosure D being earliest and coming into use just at the end of the Younger Dryas. Asouti (2017: 39-40) made use of this specific knowledge in herargument that the carvings within the enclosures represent a memory of massive climate transformation, as it is changing into legend and myth, the potential diachronic differences between the carvings can begin to weigh in on interpretation. This level of detail could not sustained has the dating of Enclosure D relied on general dating of Göbekli Tepe Level III.

The modelling study presented above shows that on the whole, a feature-oriented approach is viable, given that the relevant contexts are present and that they contain dateable material. However, building chronological syntheses based on specific contexts 
negates the "easiness" offered by thinking in terms of entire sites and forces a more nuanced approach to how we perceive the role of chronology in contextual analysis. Before tackling this issue on a theoretical level, for illustrative purposes I present two simplified examples of how feature-oriented synthesis might work in practice.

Example 1: Complex deposits in the Cypro-PPNB.

In Cyprus, the $8^{\text {th }}$ millennium BC sees the appearance of large, complex deposits (Koutrafouri 2013). These might be associated with changing ritual practices, at a time corresponding to the Middle to Late PPNB transition on the south-west Asian mainland. From this perspective, three features are of particular interest: (1) Well 23 at ParekklishaShillourokambos (hereafter Shillourokambos), an earlier shaft re-used for complex humananimal burial (Guillaine et al. 2011); (2) Feature 4 at Kritou Marattou-Ais Yiorkis (hereafter Ais Yiorkis), a structure turned into a pit, that included large flint knapping deposits, a substantial number of plant remains, and an infant burial within a cut into the feature (Simmons 2012) and (3) Well 133 at Kissonerga-Mylouthkia (hereafter Mylouthkia) notable for the deposition of 23 caprine carcasses in what may have been a single event (Peltenburg 2003). The question that interests us is when did these features form and whether they mark a distinct period in the history of the island, or form a part of a more extended tradition.

The stratigraphy of Well 23 at Shillourokambos is described in detail by Guillaine et al. (2012: 335-351). It consisted of four major stratigraphic units: the mouth of the well 
(consisting of six individual stratigraphic units), the intermediate burial deposit (three stratigraphic units), a midden and the lower well section (ibid: 339 ). The four ${ }^{14} \mathrm{C}$ dated samples (Guillaine et al. 2012: 579-581; reproduced in Supplementary Table S18 herein) derive from four of the stratigraphic units:

- $\quad$ Lyon-11634 from unit CA, a brown deposit distinct from the overlaying deposit C0 sealing the well (Guillaine et al. 2012: 342).

- Lyon-573 (OxA) from unit CB, a deposit below CA including several concentrations of charcoal (ibid: 342-3).

- Lyon-1261 (OxA) from unit CC, the complex burial deposit underneath CB (ibid: 344-345).

- Lyon-1262 (OxA), which may originate in unit $C D$, a midden deposit below the complex burial in CC (ibid: 345-351).

All of these deposits show distinct stratigraphic demarcation and it is very improbable that any substantial vertical movement took place within the feature as a whole since the deposition of the individual layers. What is less clear is whether the charred plant remains dated might have any old wood effect built into them, or whether they may be residual, with none of the samples passing the strict contextual assessment. The residuality risk is highlighted by one of the samples, Lyon-573 (OxA) (9110 \pm 90 BP; $8615-8000$ cal BC [total range of the $95.4 \%$ HPD areas]), which is far too old compared to both of the other determinations from Well 23 and the associated material culture. The four determinations are included in the broader Shillourokambos chronological model (Supplementary Figures S19-20), following the stratigraphic progression outlined above, with the material from units 
CD treated as a TPQ. This is embedded within the site model for Shillourokambos, which is summarized in detail in the Supplementary Figure S19. The results indicate that the burials (Well 23 CC) took place in 7715 - 7395 cal BC (95.4\% Probability).

Feature 4 from Ais Yiorkis is a complex pit that may have originated as a structure, was re-cut on several occasions, and provided good preservation of archaeological materials (Simmons 2012: 91). The three radiocarbon samples from this feature, which consist of charred seeds and other charred plant remains (Simmons 2012: Table 1 and Supplementary Table S17 herein), are modelled as a bounded phase (Feature 4 Phase) within the broader site model for Ais Yiorkis (Supplementary Figures S17-18). A summary parameter for the deposition of this feature (AY Feature 4) point to formation sometime in $7595-7520$ cal BC (95.4\% Probability).

The third feature of interest is Well 133 at Mylouthkia, a 5.1m deep cylindrical shaft filled by the bones of at least 23 caprines (some articulated), alongside some scattered and disarticulated human remains (Peltenburg 2003: 7). The radiocarbon record for this feature consists of three determinations: CAMS-66144, OxA-7461 and AA-33130, all of which derive from context 133.264, which is where the human and caprine remains were identified (Peltenburg 2003: Table 11.1; Supplementary Table S16 herein). One of these determinations, CAMS-66144, has been rejected on technical basis: it is a shell sample that is very depleted in ${ }^{14} \mathrm{C}$ and combines concerns about residuality with the possibility of a marine reservoir effect (see Alves et al. 2018 for an up-to date review of the subject). The other two samples consisted of a charred pistachio nut (OxA-7461) and charred ryegrass (AA-33130), both of which are short-lived samples. Note, however, that the risk of 
residuality persists and that neither of these samples passed the strict contextual assessment (Supplementary Table S16). The model (Supplementary Figures S15-16) treats the two dates as a bounded deposition with no time constraint. As one or both of the samples may suffer from some residuality, in this particular context it is more appropriate to query for the deposition date using the Last(); function, which queries the model for the date of the most recent plausible deposition in the Phase();. This approach is not a universal solution to residuality problems and it only happens to be a suitable fix in this particular case. The parameter Myl-133 Infill Last indicates that the deposition of the skeletal remains in Well 133 happened in $7185-6760$ cal BC (95.4\% Probability).

The results obtained suggest that the three deposits, Well 23 from Shillourokambos, Feature 4 from Ais Yiorkis, and Well 133 from Mylouthkia were created over the better part of a millennium and trace an extended tradition (as discussed by Koutrafouri 2013). We can also use these results to estimate the time elapsed between the formation of the different features (Figure 5). This provides the basis for estimating the tempo of development of this phenomenon and also the chronological basis for linking the earlier Cypriot examples, including Well 23 at Shillourokambos to similar practices on the mainland, most notable of which are the depositions at Kfar ha-Horesh in Gallilee (Horwitz and Goring-Morris 2004). At the same time, however, this case study also illustrates how the ability to date skeletal remains on a routine basis would improve this, and similar case studies. At Mylouthkia the low precision of the estimate is linked to the issues of potential residuality of the samples, something that would be avoided if the caprine bones could undergo direct dating. Furthermore, it would then be possible to establish the chronological relationship between 
the caprine carcasses and the human remains found in the deposit: did the human(s) die at the time of the well infill, or are these bones re-deposited from older contexts? Likewise, at Shillourokambos the ability to date the skeletal remains would make it possible to avoid any quandaries about old wood effects and residuality, thus allowing for both greater precision and greater contextual trust in the samples. That this is needed is observed in this case by the excavators themselves, in their assignment of the radiocarbon date Ly-1261 to the Shillourokambos Ancienne B phase (Guillaine et al. 2012: 580), while the burial deposit in Well 23 (Unit CC) from which it originates is attributed to the Shillourokambos Moyenne phase (ibid: 583-6). Again, direct bone dating would resolve this ambiguity.

Example 2: 'Ain Ghazal "temples".

During the 1990s excavations in the North and East fields at 'Ain Ghazal the excavators discovered several atypical buildings, at first identified as "shrines" or "temples" (Rollefson 2002; Rollefson and Kafafi 1996; 1997). While the formalised cultic status of these structures does not command universal acceptance (Finlayson 2014), these buildings do stand apart from the remainder of the PPNB architecture at the site. As such they open up the question of whether they might have been associated with family groupings (suggested by Rollefson and Kafafi 1997: 38). This possibility carries with it an interesting corollary; if the structures are contemporaneous, they could mark presence of parallel groups, perhaps based on kinship, at 'Ain Ghazal (Rollefson 2017: 111-112). 
To explore this assertion we will study the chronology of two of these structures: the building with multiple plaster floors in the North Area of excavation at 'Ain Ghazal (labelled as Shrine I by the excavators; Rollefson and Kafafi 1997: 38) and the apsidal building from the East Area of the excavation, referred to as temple by the excavator (Rollefson 1998: 8). The chronological evidence for Shrine I in the North Field comes from two fire pits (dated by samples KN-5054 and KN-5055; ibid: Table 1, data reproduced in Supplementary Table S21 herein) located in a plastered courtyard that is associated by the excavators with the use of Shrine I (Rollefson 1998: 8). As these samples come from fill of fire installations, it is very improbable that they would be residual, however, they are also unidentified charcoal and, as such, might suffer from old wood effects. Within the 'Ain Ghazal site model (Supplementary Figures S25-26) these firepits are treated as a phase (NF Shrine I assoc. firepits Phase) and their use-time is estimated using an empty date parameter (NF Shrine I Activity). The evidence for the chronology of the building in the East Field comes from two radiocarbon determinations (Rollefson 1998: Table 1; Supplementary Table S21 herein). The first of these, $\mathrm{KN}-5056$ consists of charcoal sampled from a fire pit context underneath the structured referred to by the excavator as the "temple" (Rollefson 1998: 8; Table 1). The second, AA-25425 derives from charcoal collected from the "temple" floor (ibid.). While the former sample is in what appears to be a primary context (although it may suffer from old wood effect), the description of the latter sample is insufficient to dispel doubts about its possible residual nature. As such it is treated as a terminus post quem. Within the overarching model (Supplementary Figures S25-26), material from this structure is treated as a sequence, whereby $\mathrm{KN}-5056$ is considered to pre-date the building of interest. The date 
is derived using an empty date parameter (EF Temple Activity) set to precede the TPQ provided by the sample AA- 25425 .

Taken at face value, model results imply that the two structures might be contemporaneous, with NF Shrine I Activity dating to sometime around 7430 - 6825 (95.4\% Probability) and EF Temple Activity dating to sometime around $7140-6815 \mathrm{cal}$ BC (95.4\% Probability) (Figure 6). However, this conclusion must be treated with caution. First of all, the precision of the estimates is very limited. This is, to an extent, a function of the measurement precision, but it also reflects the limited number of dates constraining these events. Then, there is also the issue of connecting the individual samples to the structures at hand, and the inability of providing meaningful dates for the beginning and ending of activity in these buildings. Hence, the possibility that these two buildings are not contemporaneous cannot be discounted. Had the excavation been taking place today and sufficient resources been available, some of these limitations could be overcome by application of microarchaeological techniques to identify a broader range of dating assemblages, thus providing the basis for a more robust treatment of the problem. Similar results could also be attained if reliable methods for dating lime plaster are developed, as this would allow us to date the individual plastering events, solving some of the dilemma, at least in Shrine I.

The two case studies provide a somewhat simplified illustration of the kinds of chronological questions that can be pursued if we begin to treat individual features as the basic analytic unit of chronological syntheses. Yet, while limited by the nature of the current published 
record, they also begin to indicate some of the conceptual and technical investments necessary for feature-based dating designs to become a reality.

1. The example of the 'Ain Ghazal shows that feature-oriented approaches to chronology need to be based on parameters with centennial, or better, precision. With Bayesian modelling as a means of constraining uncertainty on the calendar scale, this goal is achievable throughout the Holocene. However, this potential can only be fulfilled if good data are available, and this in turn requires increasing the range of contexts that can be dated well.

2. Chronological syntheses based on specific features require a much greater respect for the "granularity" of material culture and a context-by-context approach to building up of archaeological narratives. This poses both their greatest advantage and a drawback at the same time, for while this offers a much more nuanced understanding, it also means that any attempt at synthesis requires time and expertise.

3. Moving forward with the two points above requires a certain minimum quality of fieldwork. Unless the excavators are capable of identifying specific deposition events, understanding how the material recovered "fits together", and reporting this information, we cannot hope to implement feature oriented chronological syntheses. When working with archival material this also means that at times it will become necessary to work around stratigraphic uncertainty, either through building models in a way that does not enforce informative prior beliefs where uncertainty 
emerges, or through the publication of multiple models allowing for different possible stratigraphic interpretations.

It is also worth noting that thinking of chronology in terms of features contributes to the implementation of the "localist" and "contextualist" programmes outlined by Asouti (2006) or Borrell and Molist (2014), so a more feature-oriented approach to chronological synthesis contributes to the already ongoing shift towards more localized analyses of material culture (eg. Barzilai 2010, or Gebel 2010).

The one question that remains is whether feature-oriented approaches to chronology can also be implemented on the supra-regional scale. The answer is "yes", and indeed a feature-oriented approach might be more meaningful at these grand scales than comparing start/end dates for sites and settlement phases. This is because the cultural and economic variability that we are interested in manifests itself in association of archaeological material within specific contexts, something that was already understood by Childe (1929; also consider Clarke 1968). Treating specific contexts as the basic unit of chronological synthesis, allows us to bring the material within them back to the fore, alongside any granularity it might imply. As such, the synthesis would happen at the level of the specific types of specific remains, thus contributing to changing our perception of culture-historical constructs from static large-scale blocks separated by periods of abrupt change, into entities whose underpinning components can be traced through time (see also Campbell 2007; Philip 2011). Needless to say, if the transition between the two culture historical groupings was indeed abrupt across various forms of material culture and 
economic choices, then the feature-oriented approach would identify it as such. Its true power, however, lies in the ability to describe the nuanced and the complex as such.

\section{Conclusions and future developments}

This paper covered the state of a selection of ${ }^{14} \mathrm{C}$ legacy data from the earlier Holocene of the Levant and outlined some ways that we can improve both the quality of individual radiocarbon determinations, as well as their articulation with cultural investigations. The immediate conclusion from the first part of the paper, consisting of an assessment of a selection of published ${ }^{14} \mathrm{C}$ data, is that there are very few contexts throughout the region that have reliable radiocarbon dates. While this, is to an extent, the effect of outdated practices, such as submitting unidentified charred plant remains for ${ }^{14} \mathrm{C}$ dating, the root cause is that the sites themselves provide only a small number of contexts that can be considered reliable in the first place. In the long-term, developing the capacity to date skeletal remains from the Levant on a routine, or semi-routine basis is the most powerful means of overcoming this limitation. In the meantime, substantial progress might be achieved through improving context descriptions through microarchaeological techniques, as well as extending our understanding of charred plant remains and how they are integrated into archaeological sites.

The second part of the paper brings forward two main observations. First of these is that the legacy radiocarbon record cannot carry us much further than it has. The models presented in this paper show limited overall precision of the parameters of interest and confirms doubts expressed by Ibáñez et al. (2018: 245). Having said that, the outlook is far 
more positive: legacy data only represent the past state of affairs and not the developing situation. During the late 2000s and 2010s, both the number and the contextual quality of radiocarbon dates from the earlier Holocene of the Levant and south-west Asia in general has improved. Çatalhöyük (Bayliss et al. 2015; Marciniak et al. 2015) is a flagship example, but many ongoing projects see similar improvements reproduced on a smaller scale (e.g. Baird et al. 2018; Miyake et al. 2012; Vigne et al. 2012). Here, the increased use of microarchaeological analyses combined with better excavation techniques plays a fundamental role in delivering better radiocarbon chronologies. At the same time, however, there is a growing need to improve the chronology of sites that will keep playing a part in our discussions in the near future. Observations and material from locations such as 'Ain Ghazal, or Mureybet will continue to be referred to and so it is important that their chronology keeps in step with recent developments. Experience from the UK demonstrate that site archives can be re-dated to a modern resolution (Hamilton et al. 2015), even where the fieldwork took place in the 1950s and 1960s (Bayliss et al. 2007; Whittle et al. 2007; Wysocki et al. 2007). In such cases, the ability to date skeletal remains might prove essential as, in the absence of modern excavation techniques, records of burials might prove to be the main source of evidence for contextual reliability.

The other key observation from the second part of the paper is that a shift towards individual contexts as basic units of chronological synthesis might be essential to resolving some of chronological ambiguity. In some respects this is already taking place, as seen in the example of the discussion of the atypical burial at Ba'ja (Benz et al. 2019), or in the case of Dietrich et al.'s (2013) discussion of the ambiguities in the chronology of Layer III at Göbekli 
tepe. While this is not the only way that we may revise chronology construction (see e.g. Watkins 2013: 153-4 for an alternative scheme), the fact remains that our radiocarbon samples always come from specific contexts and may not always conform to the abstractions we wish to impose on them. These abstractions are a result of much of our thinking about the earlier Holocene of the Levant taking place in terms of sites as analytical units, similar to how thinking in culture-historical terms drives the structure of chronology building in the three millennia that follow 6,000 cal BC (Banning 2007, Campbell 2007). Yet in very much the same way, satisfactory resolution of the emerging chronological tension and ambiguity lies in paying greater attention to the granular nature of the radiocarbon record (Banning 2007; Campbell 2007; Philip 2011). It is through attention to the contexts we are dating, and through the extension of the range of contexts that we can date well, that the clarity of earlier Holocene Levantine radiocarbon chronologies can improve and pave the way for more nuanced archaeological interpretation that can better face to the complexity of these millennia.

Acknowledgements, This research was made possible by a CBRL Visiting Research Fellowship. The author would like to thank the two anonymous reviewers for both their substantial contribution to the quality and readability of this paper, as well as their patience. Same thanks extend to the editorial team of the Levant and Jessica Bownes.

References 
Ajie, H. O., Kaplan, I. R, Hauschke, P. V., Kirner, D., Slota, P. J. and Taylor, R.E. 1992. Radiocarbon dating of bone osteocalcin: isolating and characterizing a non-collagen protein. Radiocarbon 34(3): 296-305.

Alves, E. Q., Macario, K., Ascough, P. and Bronk Ramsey, C. 2018 The worldwide marine radiocarbon reservoir effect: definitions, mechanisms, and prospects. Reviews of Geophysics 56(1): 278-305.

Asouti, E. 2006. Beyond the Pre-Pottery Neolithic B interaction sphere. Journal of World Prehistory 20(2): 87-126.

Asouti, E. 2017. Human palaeoecology in Southwest Asia during the Early Pre-Pottery Neolithic (c. 9700-8500 cal BC): the plant story. In: Benz, M., Gebel, H. G. K. and Watkins, T. (eds), Neolithic Corporate Identities: 21-53. Berlin: Ex Oriente.

Asscher, Y., Lehmann, G., Rosen, S. A., Weiner, S. and Boaretto, E. 2015a. Absolute dating of the late Bronze to Iron Age transition and the appearance of Philistine culture in Qubur el-Walaydah, southern Levant. Radiocarbon 57(1): 77-97.

Asscher, Y., Cabanes, D., Hitchcock, L. A., Maeir, A. M., Weiner, S. and Boaretto, E. 2015b. Radiocarbon dating shows an early appearance of Philistine material culture in Tell es-Safi/Gath, Philistia. Radiocarbon 57(5): 825-850.

Aurenche, O., Galet, P., Régagnon-Caroline, E. and Évin, J. 2001. Proto-Neolithic and Neolithic cultures in the Middle East-the birth of agriculture, livestock raising, and ceramics: a calibrated ${ }^{14} \mathrm{C}$ chronology $12,500-5500$ cal BC. Radiocarbon 43(3): 11911202.

Austin, P. 2007. The wood charcoal. In Finlayson, S. and Mithen, S. (eds), The early prehistory of Wadi Faynan, southern Jordan. Archaeological survey of Wadis Faynan, Ghuwayr and al-Bustan and evaluation of the Pre-Pottery Neolithic A site of WF16: 408-419. Oxford: Oxbow Books.

Baird, D., Fairbairn, A., Jenkins, E., Martin, L., Middleton, C., Pearson, J., Asouti, E., Edwards, Y., Kabukcu, C, Mustafaoğlu, G., Russell, N., Bar-Yosef, O., Jacobsen, G., We, X., Baker, A. and Elliott, S. 2018. Agricultural origins on the Anatolian plateau. 
Proceedings of the National Academy of Sciences of the United States of America 115(14): E3077-E3086.

Banning, E. B. 2007. Wadi Rabah and related assemblages in the southern Levant: interpreting the radiocarbon evidence. Paleorient 33(1): 77-101.

Barzilai, O. 2010. Social Complexity in the Southern Levantine PPNB as Reflected through Lithic Studies. The bidirectional blade industries. Oxford: Archaeopress.

Barzilai, O., Rebollo, N., Nadel, D., Bocquentin, F., Yeshurun, R., Lengyel, G., Bermatov-Paz, G. and Boaretto, E. 2017. Radiocarbon dating of human burials from Raqefet Cave and contemporaneous Natufian traditions at Mount Carmel. Antiquity 91: 11371154.

Bayliss, A., Whittle, A. and Wysocki, M. 2007. Talking about my generation: the date of the West Kennet Long Barrow. Cambridge Archaeological Journal 17(1): 85-101.

Bayliss, A., Brock, F., Farid, S., Hodder, I., Southon, J. and Taylor, R. E. 2015. Getting to the Bottom of It All: A Bayesian Approach to Dating the Start of Çatalhöyük. Journal of World Prehistory 28(1): 1-26.

Beer, J., McCracken, K. and Steiger, R. 2012. Cosmogenic Radionuclides: Theory and Applications in the Terrestrial and Space Environments. Heidelberg: Springer.

Benz, M., Gresky, J., Štefanisko, D., Alarashi, H., Knipper, C., Purschwitz, C., Bauer, J., Gebel, H. G. K. 2019. Burying power: New insights into incipient leadership in the Late PrePottery Neolithic from an outstanding burial at Ba'ja, southern Jordan. PLOS One 14(8): e0221171. https://doi.org/10.1371/journal.pone.0221171

Boaretto, E. 2009. Dating materials in good archaeological contexts: the next challenge for radiocarbon analysis. Radiocarbon 51(1): 275-281.

Boaretto, E. 2015. Radiocarbon and the archaeological record: an integrative approach for building an absolute chronology for the late Bronze and Iron ages of Israel. Radiocarbon 57(2): 207-216.

Borrell, F. and Mollist, M. 2014. Social interaction at the end of the Pre-Pottery Neolithic B: an Inter-site Analysis in the Euphrates Valley. Cambridge Archaeological Journal 24(2): $215-31$. 
Borrell, F., Junno, A. and Barceló, J. A. 2015. Synchronous Environmental and Cultural Change in the Emergence of Agricultural Economies 10,000 Years Ago in the Levant. PLOS One 10(8): e0134810. https://doi.org/10.1371/journal.pone.0134810

Brock, F., Higham, T., Ditchfield, P. and Bronk Ramsey, C. 2010. Current pretreatment methods for AMS radiocarbon dating at the Oxford radiocarbon accelerator unit (ORAU). Radiocarbon 52(1): 103-112.

Bronk Ramsey, C. 2009a. Dealing with outliers and offsets in radiocarbon dating. Radiocarbon, 51(3), 1023-1045.

Bronk Ramsey, C. 2009b. Bayesian analysis of radiocarbon dates. Radiocarbon, 51(1), 337360.

Bronk Ramsey, C. 2017. Methods for summarizing radiocarbon datasets. Radiocarbon 59(6): 1809-1833.

Buck, C. E., Cavanagh, W. G. and Litton, C. D. 1996. Bayesian approach to interpreting archaeological data. Chichester: Wiley.

Campbell, S. 2007 Rethinking Halaf chronologies. Paleorient 33(1): 103-136.

Childe, V. G. 1929. The Danube in prehistory. Oxford: The Clarendon Press.

Clarke, D. L. 1968. Analytical archaeology. London: Methuen and Company Ltd.

Cleland, T. P. and Vashishth, D. 2015 Bone protein extraction without demineralization using principles from hydroxyapatite chromatography. Analytical Biochemistry 472: 62-66.

Contreras, D. A. and Meadows, J. 2014. Summed radiocarbon calibrations as a population proxy: a critical evaluation using a realistic approach. Journal of Archaeological Science 52: 591-608.

Devièse, T., Comeskey, D., McCullagh, J., Bronk Ramsey, C. and Higham, T. 2017. New protocol for compound-specific radiocarbon analysis of archaeological bones. Rapid communications in mass spectrometry 32: 373-379.

Dietrich, O., Köksal-Schmidt, Ç., Notroff, J. and Schmidt, K. 2013. Establishing a Radiocarbon Sequence for Göbekli Tepe. State of Research and New Data. Neo-Lithics 1/13: 3641. 
Dobberstein, R. C., Collins, M. J., Craig, O. E., Taylor, G., Penkman, K. E. H. and Ritz-Timme, S. 2009. Archaeological collagen: why worry about collagen diagenesis? Archaeological and Anthropological Sciences 1(1): 31-42.

Edwards, P. C., 2016. The chronology and dispersal of the Pre-pottery Neolithic B cultural complex in the Levant. Paléorient 42(2): 53-72.

Evin, J. and Stordeur, D. 2008. Chronostratigraphie de Mureybet. Apport des datations des radiocarbone. In Ibáñez, J. J. (ed), Le site néolithique de Tell Mureybet (Syrie du Nord). En homage à Jacques Cauvin: 21-32. Oxford: Archaeopress.

Faust, A. and Sapir, Y. 2018. The "Governor's Residency" at Tel 'Eton, The United Monarchy, and the Impact of the Old-House Effect on Large-Scale Archaeological Reconstructions. Radiocarbon 60(3): 801-820.

Finlayson, B. 2014. Houses of the Holy: the Evolution of Ritual Buildings. In Finlayson, B. and Makarewicz, C. (eds), Settlement, Survey, and Stone: Essays on Near Eastern Prehistory in Honour of Gary Rollefson: 133-143. Berlin: Ex Oriente.

Fishman, B. and Lawn, B. 1978. University of Pennsylvania radiocarbon dates XX. Radiocarbon 20(2): 210-233.

Fitzpatrick, S. M. 2006. A critical approach to ${ }^{14} \mathrm{C}$ dating in the Carribean: using chronometric hygiene to evaluate chronological control and prehistoric settlement. Latin American Antiquity 17(4): 398-418.

Flohr, P., Fleitmann, D., Matthews, R., Matthews, W. and Black, S. 2016. Evidence of resilience to past climate change in Southwest Asia: Early farming communities and the 9.2 and 8.2 ka events. Quaternary Science Reviews 136: 15-39.

Fort, J., Pujol, T., and Vander Linden, M. 2012. Modelling the Neolithic transition in the Near East and Europe. American Antiquity 77(2):203-219.

Garfinkel, Y., Dag, D., Khalaily, H., Marder, O., Milevski, I. I. and Ronen, A. 2012. The PrePottery Neolithic B Village of Yiftahel. The 1980s and 1990s Excavations. Berlin: ex Oriente. 
Garrard, A., Edward, Y., Stock, J. and Yazbeck, C. 2018. Epipalaeolithic and Pre-Pottery Neolithic burials from the north Lebanese highlands in their regional context. Levant 50(1): 1-13.

Gebel, H. G. K. 2010. Commodification and the formation of Early Neolithic social identity. The issues as seen from the southern Jordanian Highlands. In: Benz, M. (ed.), The Principle of Sharing. Segregation and construction of social identities at the transition from foraging to farming: 35-80. Berlin: ex Oriente.

Gebel, H. G. K. and Kinzel, M. 2007. Ba'ja 2007: crawl spaces, rich room dumps, and high energy events. Results of the 7th season of excavations. Neo-Lithics 1/07: 24-32.

Goldenberg, L., Regev, L., Mintz, E. and Boaretto, E. 2017. Dating reassembled collagen from fossil bones. Radiocarbon 59(5): 1487-1496.

Gopher, A. 1994. Arrowheads of the Neolithic Levant: A Seriation Analysis. Winona Lake, Indiana: Eisenbrauns.

Grupe, G. 1995. Preservation of collagen in bone from dry, sandy soil. Journal of Archaeological Science 22: 193-199.

Guillaine, J., Briois, F. and Vigne, J.-D. 2011. Shillourokambos. Un etablissement neolithique pre-ceramique a Chypre. Les fouilles du secteur 1. (Vol. 1). Paris: Editions Errance.

Gur-Arieh, S., Mintz, E., Boaretto, E. and Shahack-Gross, R. 2013. An ethnoarchaeological study of cooking installations in rural Uzbekistan: development of a new method for identification of fuel sources. Journal of Archaeological Science 40(12): 4331-4347.

Hamilton, W. D., Haselgrove, C. and Gosden, C. 2015. The impact of Bayesian chronologies on the British Iron Age. World Archaeology 47(4): 642-660.

Henry, D. O. and Servello, A. F. 1974. Compendium of carbon-14 determinations derived from near Eastern prehistoric deposits. Paléorient 2(1):19-44.

Hoff, P. D. 2009. A first course in Bayesian statistical methods. New York: Springer.

Horwitz, L. K. and Goring-Morris, N. 2004. Animals and ritual during the Levantine PPNB: a case study from the site of Kfar Hahoresh, Israel. Anthropozoologica 39(1): 465-178. 
Ibáñez, J. J., Gonzáles-Urquijo, J., Teira-Mayolini, L. C. and Lazuén, T. 2018. The emergence of the Neolithic in the Near East: A protracted and multi-regional model. Quaternary Intternational 470: 226-252.

Jakucs, J., Bánffy, E., Oross, K., Voicsek, V., Bronk Ramsey, C., Dunbar, E., Kromer, B., Bayliss, A., Hofmann, D., Marshall., P. and Whittle, A. 2016. Between Vinča and Linearbandkeramik worlds: the diversity of practices and identities in the $54^{\text {th }}-53^{\text {rd }}$ centuries cal BC in southwest hungary and beyond. Journal of World Prehistory 29:267-336.

Jenkins, E. L., Allcock, S. L., Elliott, S., Palmer, C. and Grattan, J. 2017. Ethno-geochemical and phytolith studies of activity related patterns: a case study from Al Ma'tan, Jordan. Environmental Archaeology 22(4): 412-433.

Khalaily, H., Bar-Yosef, O., Barzilai, O., Boaretto, E., Bocquetin, F., Le Dosseur, G., EirikhRose, A., Goring-Morris, A. N., Greenhut, Z., Marder, O., Sapir-Hen, L. and Yizhaq, M. 2007. Excavations at Motza in the Judean Hills and the Early Pre-Pottery Neolithic B in the Southern Levant. Paléorient 33(2): 5-37.

Koutrafouri, V. G. 2008. Ritual in Prehistory; Definition and Identification. Religious Insights in Early Prehistoric Cyprus. Unpublished doctoral thesis. School of History, Classics and Archaeology. University of Edinburgh.

Koutrafouri, V. G. 2013. From wells to pillar and from pillars to...? Ritual systems and collapse in the early prehistory of Cyprus. In: Koutrafouri, V. and Sanders, J. (eds.), Ritual Failure. Archaeological perspectives: 85-108. Leiden: Sidestone Press. Lanos, P. and Phillipe, A. 2015. Hierarchical Bayesian modeling for combining Dates in archaeological context. https://hal.archives-ouvertes.fr/hal-01162404v3 Le Brun, A. 1984. Fouilles récentes à Khirokitia (Chypre), 1977-1981. Paris: Éditions Recherche sur les civilisations.

Le Brun, A. 1989. Fouilles récentes à Khirokitia (Chypre), 1983-1986. Paris: Éditions Recherche sur les civilisations.

Le Brun, A. 1994. Fouilles récentes à Khirokitia (Chypre), 1988-1991. Paris: Éditions Recherche sur les civilisations. 
Le Brun, A. and Daune-Le Brun, O. 2009. Khirokitia (Chypre): la taille et les pulsations de l'établissement néolithique pré-céramique, nouvelles données. Paléorient 35(2): 6978.

Longin, R. 1971. New Method of Collagen Extraction for Radiocarbon Dating. Nature 230: 241-242.

Maher, L. A., Banning, E. B. and Chazan, M. (2011). Oasis or Mirage? Assessing the Role of Abrupt Climate Change in the Prehistory of the Southern Levant. Cambridge Archaeological Journal 21(1): 1-30.

Marciniak, A., Baranski, M. Z., Bayliss, A., Czerniak, L., Goslar, T., Southon, J. and Taylor, R. E. 2015. Fragmenting times: interpreting a Bayesian chronology for the Late Neolithic occupation of Çatalhöyük East, Turkey. Antiquity 89: 154-176.

Marom, A., McCullagh, J. S., Higham, T. F., Sinitsyn, A. A. and Hedges, R. E. 2012. Single amino acid radiocarbon dating of Upper Paleolithic modern humans. Proceedings of the National Academy of Sciences of the United States of America 109(18): 68786881.

McCullagh, J. S., Marom, A. and Hedges, R. E. 2010. Radiocarbon dating of individual amino acids from archaeological bone collagen. Radiocarbon 52(2-3): 620-634.

Miyake, Y., Maeda, O., Tanno, K., Hongo, H. and Gündem, C. Y. 2012. New excavations at Hasankeyf Höyük: a $10^{\text {th }}$ millennium cal. BC site on the Upper Tigris, southeast Anatolia. Neo-Lithics 1/12: 1-5.

Moore, A. M. T. 1992. The Impact of Accelerator Dating at the Early village of Abu Hureyra on the Euphrates. Radiocarbon 34(3): 850-858.

Moore, A. M. T., Hillman, G. C. and Legge, A. J. 2000. Village on the Euphrates: From foraging to farming at Abu Hureyra. London: Oxford University Press.

Nalawade-Chavan, S., Zazula, G., Brock, F., Southon, J., MacPhee, R. and Druckenmiller, P. 2014. New single amino acid hydroxyproline radiocarbon dates for two problematic American Mastodon fossils from Alaska. Quaternary Geochronology 20: 23-28.

Peltenburg, E. 2003. Colonization of Cyprus: investigations at Kissonerga-Mylouthkia, 19761996. Sävedalen: Paul Åströms förelag. 
Philip, G. 2011. The later prehistory of the Southern Levant: issues of practice and context. In: Lovell, J. L. and Rowan, Y. M. (eds.) Culture, chronology and the Chalcolithic. Theory and transition: 192-209. Oxford and Oakville: Oxbow Books.

Pinhasi, R., Fort, J., and Ammerman, A. J. 2005. Tracing the origin and spread of agriculture in Europe. Public Library of Science Biology 3: 2220-2228.

Plug, H., van der Plicht, J. and Akkermans, P. M. 2014. Tell Sabi Abyad, Syria: dating of Neolithic cemeteries. Radiocarbon 56(2): 543-554.

Reimer, P.J., Bard, E., Bayliss, A., Warren Beck, J., Blackwell, P.G., Bronk Ramsey, C., Buck, C.E., Cheng, H., Lawrence Edwards, R., Friedrich, M., Grootes, P.M., Guilderson, T.P., Haflidason, H., Hajdas, I., Hatte, C., Heaton, T.J., Hoffmann, D.L., Hogg, A.G., Hughen, K.A., Kaiser, K.F., Kromer, B., Manning, S.W., Niu, M., Reimer, R.W., Richerds, D.A., Scott, E.M., Southon, J.R., Staff, R.A., Turney, C.S.M. and van der Plicht, J. 2013. IntCal13 and Marine13 Radiocarbon Age Calibration Curves 0 - 50,000 Years cal BP. Radiocarbon 55(4): 1869-1887.

Reynolds, N., Dinnis, R., Bessudnov, A. A., Devièse, T. and Higham, T. 2017 The Kostenki 18 child burial and the cultural and funerary landscape of Mid Upper Palaeolithic European Russia. Antiquity 91:1435-1450.

Rollefson, G. O. 1998. Expanded Radiocarbon Chronology from 'Ain Ghazal. Neo-Lithics 98/2: 8-10.

Rollefson, G. O. 2002. Ritual and Social Structure at Neolithic 'Ain Ghazal. In Kuijt, I. (ed), Life in Neolithic Farming Communities. Social Organization, Identity and Differentiation: 165-190. New York: Kluwer Academic Publishers.

Rollefson, G. O. 2017. "I am We": The display of socioeconomic politics of Neolithic commodification. In: Benz, M., Gebel, H. G. K. and Watkins, T. (eds), Neolithic Corporate Identities: 107-116. Berlin: Ex Oriente.

Rollefson, G. O. and Kafafi, Z. 1996. The 1995 Season at 'Ain Ghazal: Preliminary Report. Annual of the Department of Antiquities of Jordan 40: 11-28.

Rollefson, G. O. and Kafafi, Z. 1997. The 1996 Season at 'Ain Ghazal: Preliminary Report. Annual of the Department of Antiquities of Jordan 41: 27-48. 
Salamon, M., Tzur, S., Arensburg, B., Zias, J., Nagaer, Y., Weiner, S. and Boaretto, E. 2010. Ancient mtDNA sequences and radiocarbon dating of human bones from the Chalcolithic caves of Wadi el-Makkukh. Mediterranean Archaeology and Archaeometry 10(2): 1-14.

Schiffer, M. B. 1986. Radiocarbon dating and the "old wood" problem: the case of the Hohokam chronology. Journal of Archaeological Science 13(1): 13-30.

Scirè Calabrisotto, C., Amadio, M., Fedi, M. E., Liccioli, L. and Bombardieri, L. 2017. Strategies for Sampling Difficult Archaeological Contexts and Improving the Quality of Radiocarbon Data: The Case of Erimi Laonin Tou Porakou, Cyprus. Radiocarbon 59(6): 1919-1930.

Simmons, A. H. 2012. Ais Giorkis: An unusual early Neolithic settlement in Cyprus. Journal of Field Archaeology 37(2); 86-103.

Spriggs, M. 1989. The dating of the Island Southeast Asian Neolithic: an attempt at chronometric hygiene and linguistic correlation. Antiquity 63: 587-613.

Stuiver, M. and Reimer, P. 1986. A computer program for radiocarbon age calibration. Radiocarbon 28(2B): 1022-1030.

Taché, K. and Hart, J. P. 2013. Chronometric hygiene of radiocarbon databases for early durable cooking vessel technologies in northeastern North America. American Antiquity 78(2): 359-372.

Toffolo, M., Maeir, A. M., Chadwick, J. R. and Boaretto, E. 2012. Characterization of Contexts for Radiocarbon Dating: Results from the Early Iron Age at Tell Es-Safi/Gath, Israel. Radiocarbon 54(3-4): 371-390.

van der Plicht, J. 1993. The Groningen radiocarbon calibration program. Radiocarbon 35(1): 231-237.

van der Plicht, J., Akkermans, P. M., Nieuwenhuyse, O., Kaneda, A. and Russel, A. 2011. Tell Sabi Abyad, Syria: radiocarbon chronology, cultural change and the 8.2 ka event. Radiocarbon 53(2): 229-243.

Vigne, J.-D., Briois, F., Zazzo, A., Willcox, G., Cucchi, T., Thiébault, S., Carrère, I., Franel, Y., Touquet, R., Martin, C., Moreau, C., Comby, C. and Guilaine, J. 2012. First wave of 
cultivators spread to Cyprus at least 10,600 y ago. Proceeding of the National Academy of Sciences of the United States of America 109(22): 8445-8449.

Watkins, T. F. 2013. The Neolithic in transition - how to complete a paradigm shift. Levant 45(2): 149-153.

Weiner, S. 2010. Microarchaeology: beyond the visible archaeological record. Cambridge: Cambridge University Press.

Weiner, S. and Bar-Yosef, O. 1990. States of preservation of bones from prehistoric sites in the Near East: a survey. Journal of Archaeological Science 17(2): 187-196.

Weinstein-Evron, M., Yeshurun, R., Kaufman, D., Eckmeier, E. and Boaretto, E. 2012. New ${ }^{14} \mathrm{C}$ Dates for the Early Natufian of El-Wad Terrace, Mount Carmel, Israel. Radiocarbon 54: 813-822.

Weninger, B., Joris, O. and Danzeglocke, U. 1986-2016. Cologne Radiocarbon Calibration \& Paleaoclimate Research Package <CALPAL $>$.

Weninger, B., Clare, L., Joris, O., Jung, R. and Edinborough, K. 2015. Quantum theory of radiocarbon calibration. World Archaeology 47(4): 543-566.

Whittle, A. W. R. 2018. The Times of Their Lives. Oxford and Philadelphia: Oxbow Books. Whittle, A., Bayliss, A. and Wysocki, M. 2007. Once in a lifetime: the date of the Wayland's Smithy Long Barrow. Cambridge Archaeological Journal 17(1): 103-121.

Whittle, A. W. R., Healy, F. M. and Bayliss, A. 2011. Gathering Time: Dating the Early Neolithic Enclosures of Southern Britain and Ireland. Oxford: Oxbow Books.

Wicks, K., Finlayson, B., Maričević, D., Smith, S., Jenkins, E. and Mithen, S. 2016. Dating WF16: Exploring the Chronology of a Pre-Pottery Neolithic A Settlement in the Southern Levant. Proceedings of the Prehistoric Society 82: 1-51.

Wysocki, M., Bayliss, A . and Whittle, A. 2007. Serious mortality: the date of the Fussell's Lodge Long Barrow. Cambridge Archaeological Journal 17(1): 65-84.

Yizhaq, M., Mintz, G., Cohen, I., Khalaily, H., Weiner, S. and Boaretto, E. 2005. Quality controlled radiocarbon dating of bones and charcoal from the early Pre-Pottery Neolithic B (PPNB) of Motza (Israel). Radiocarbon 47(2): 193-206. 
Zazzo, A. and Saliège, J.-F. 2011. Radiocarbon dating of biological apatites: A review. Palaeogeography, Palaeoclimatology, Palaeoecology 310(1-2): 52-61.

Zazzo, A., Saliège, J.-F., Lebon, M., Lepetz, S. and Moreau, C. 2012. Radiocarbon dating of calcinated bones: insights from combustion experiments under natural conditions. Radiocarbon 54(3-4): 855-866. 
Tables and Figures

Table 1. Assessment criteria. *For radiocarbon ages, the ranges are deemed inacceptable and demonstrating technical difficulties in the case of multi-millennial offsets (eg. 20,000 year-old samples in secure MPPNB contexts), or where it conflicts with other, more coherent, sets of radiocarbon determinations.

\begin{tabular}{|c|c|c|}
\hline Technical criteria & Strict contextual criteria & Relaxed contextual criteria \\
\hline $\begin{array}{l}\text { Did the sample undergo } \\
\text { suitable pre-treatment? } \\
\text { Has the sample been } \\
\text { measured with reference to } \\
\text { the international standard, } \\
\text { or otherwise has its age } \\
\text { been corrected to it? } \\
\text { How was the sample error } \\
\text { calculated? } \\
\text { What was the measurement } \\
\text { method used? } \\
\text { Is the radiocarbon age and } \\
\text { the }{ }^{13} \text { C ratio within } \\
\text { acceptable ranges?* }\end{array}$ & $\begin{array}{l}\text { The sample has } \\
\text { unambiguous connection to } \\
\text { the feature in question. }\end{array}$ & $\begin{array}{l}\text { There are sufficient grounds } \\
\text { for belief that the sample is } \\
\text { associated with the feature, } \\
\text { or level, in which it was } \\
\text { found. } \\
\text { There are no unresolved } \\
\text { stratigraphic contradictions } \\
\text { relating to the sample. }\end{array}$ \\
\hline
\end{tabular}


Table 2. Assessment results * CPR stands for charred plant remains, including both charcoal and other charred plants, including seeds. ${ }^{* *}$ Bone includes mineral and non-mineral fractions, both burnt and un-burnt, as well as teeth. $* * *$ Other materials includes shell, plaster and sediment samples.

\begin{tabular}{|c|c|c|c|c|c|c|c|c|c|c|c|c|c|}
\hline Site & 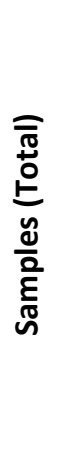 & $\begin{array}{l}\overline{\bar{J}} \\
\stackrel{0}{0} \\
\stackrel{E}{*} \\
\stackrel{*}{0} \\
\stackrel{0}{0}\end{array}$ & 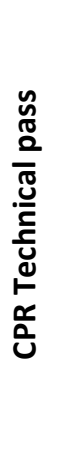 & 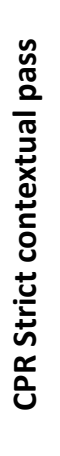 & 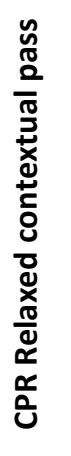 & 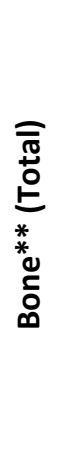 & 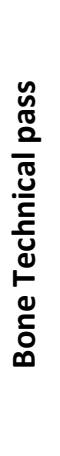 & 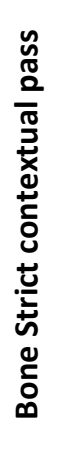 & 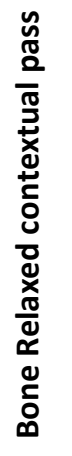 & 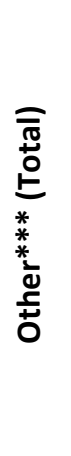 & 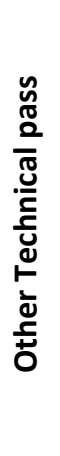 & 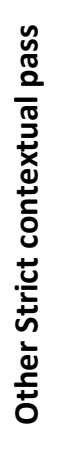 & 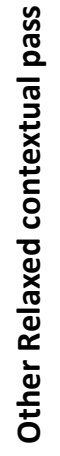 \\
\hline Abu Hureyra & 71 & 42 & 42 & 1 & 10 & 19 & 0 & 0 & 0 & 10 & 0 & 0 & 0 \\
\hline Akanthou-Arkosyko & 2 & 2 & 2 & 0 & 2 & 0 & 0 & 0 & 0 & 0 & 0 & 0 & 0 \\
\hline $\begin{array}{c}\text { Akrotiri- } \\
\text { Aetokramnos }\end{array}$ & 71 & 10 & 8 & 0 & 8 & 48 & 11 & 0 & 11 & 13 & 0 & 0 & 0 \\
\hline Ain Ghazal & 82 & 73 & 70 & 5 & 48 & 7 & 0 & 0 & 0 & 2 & 0 & 0 & 0 \\
\hline $\begin{array}{c}\text { Ayia Napa-Nissi } \\
\text { Beach }\end{array}$ & 2 & 0 & 0 & 0 & 0 & 0 & 0 & 0 & 0 & 2 & 0 & 0 & 0 \\
\hline $\begin{array}{l}\text { Ayia Varvara- } \\
\text { Asprokremnos }\end{array}$ & 17 & 17 & 16 & 0 & 16 & 0 & 0 & 0 & 0 & 0 & 0 & 0 & 0 \\
\hline $\begin{array}{c}\text { Ayios Tychonas- } \\
\text { Klimonas }\end{array}$ & 23 & 11 & 11 & 0 & 11 & 12 & 0 & 0 & 0 & 0 & 0 & 0 & 0 \\
\hline Ayn Abu Nukhalya & 12 & 12 & 12 & 0 & 7 & 0 & 0 & 0 & 0 & 0 & 0 & 0 & 0 \\
\hline Basta & 12 & 8 & 8 & 0 & 2 & 0 & 0 & 0 & 0 & 4 & 4 & 0 & 0 \\
\hline Beidha & 30 & 29 & 29 & 1 & 14 & 1 & 0 & 0 & 0 & 0 & 0 & 0 & 0 \\
\hline $\begin{array}{l}\text { Cap Andreas- } \\
\text { Kastros }\end{array}$ & 3 & 0 & 0 & 0 & 0 & 0 & 0 & 0 & 0 & 3 & 0 & 0 & 0 \\
\hline Dahli-Agridhi/Site E & 3 & 3 & 3 & 0 & 0 & 0 & 0 & 0 & 0 & 0 & 0 & 0 & 0 \\
\hline Ghuwayr I & 21 & 21 & 21 & 0 & 14 & 0 & 0 & 0 & 0 & 0 & 0 & 0 & 0 \\
\hline Kalavasos-Tenta & 21 & 21 & 5 & 0 & 5 & 0 & 0 & 0 & 0 & 0 & 0 & 0 & 0 \\
\hline Khirokitia-Vounoi & 30 & 27 & 27 & 0 & 9 & 3 & 0 & 0 & 0 & 0 & 0 & 0 & 0 \\
\hline
\end{tabular}




\begin{tabular}{|c|c|c|c|c|c|c|c|c|c|c|c|c|c|}
\hline Kholetria-Ortos & 6 & 4 & 4 & 0 & 0 & 1 & 0 & 0 & 0 & 1 & 0 & 0 & 0 \\
\hline $\begin{array}{l}\text { Kissonerga- } \\
\text { Mylouthkia }\end{array}$ & 8 & 5 & 5 & 0 & 5 & 0 & 0 & 0 & 0 & 3 & 0 & 0 & 0 \\
\hline $\begin{array}{c}\text { Kritou Marottou-Ais } \\
\text { Yiorkis }\end{array}$ & 26 & 17 & 16 & 4 & 16 & 4 & 0 & 0 & 0 & 5 & 0 & 0 & 0 \\
\hline $\begin{array}{c}\text { Parekklisha- } \\
\text { Shillourokambos }\end{array}$ & 37 & 35 & 35 & 0 & 32 & 2 & 0 & 0 & 0 & 0 & 0 & 0 & 0 \\
\hline Tell es-Sultan & 45 & 45 & 27 & 0 & 20 & 0 & 0 & 0 & 0 & 0 & 0 & 0 & 0 \\
\hline Yiftahel & 25 & 16 & 16 & 12 & 14 & 0 & 0 & 0 & 0 & 9 & 0 & 0 & 0 \\
\hline Total & 547 & 398 & 357 & 23 & 233 & 97 & 11 & 0 & 11 & 52 & 4 & 0 & 0 \\
\hline
\end{tabular}

Table 3 Results of the modelling study.

\begin{tabular}{|c|c|c|c|c|}
\hline Parameter type & Site & Parameter Name & $\begin{array}{l}\text { Precision } 68.2 \% \\
\text { probability }\end{array}$ & $\begin{array}{c}\text { Precision } 95.4 \% \\
\text { probability }\end{array}$ \\
\hline Site Onset & $\begin{array}{l}\text { Parekklisha- } \\
\text { Shillourokambos }\end{array}$ & Shillourokambos Onset Boundary & 170 & 330 \\
\hline Site termination & None & & & \\
\hline \multirow[t]{16}{*}{ Feature Date } & $\begin{array}{l}\text { Ayia Varvara- } \\
\text { Asprokremnos }\end{array}$ & AVA F130 & 60 & 150 \\
\hline & $\begin{array}{l}\text { Ayios Tychonas- } \\
\text { Klimonas }\end{array}$ & St10-SU 10.6 break Boundary & 55 & 125 \\
\hline & Ain Ghazal & Statuary 3076.051 & 220 & 345 \\
\hline & & Large LPPNB bdg Destruction & 90 & 215 \\
\hline & & NF Shrine I Activity & 275 & 605 \\
\hline & & EF Temple Activity & 140 & 325 \\
\hline & Beidha & Bdg 18 Construction & 175 & 405 \\
\hline & & Bdg 48 Construction & 175 & 405 \\
\hline & & Bdg 74 Construction & 175 & 400 \\
\hline & & Bdg 54 Conflagration & 175 & 415 \\
\hline & & Bdg 26 Construction & 200 & 495 \\
\hline & $\begin{array}{l}\text { Kissonerga- } \\
\text { Mylouthkia }\end{array}$ & Myl-116.124 Infill & 265 & 825 \\
\hline & & Myl-133.264 Infill Last & 210 & 390 \\
\hline & $\begin{array}{l}\text { Kritou Morottou-Ais } \\
\text { Yiorkis }\end{array}$ & AY Feature 4 & 40 & 75 \\
\hline & $\begin{array}{l}\text { Parekklisha- } \\
\text { Shillourokambos }\end{array}$ & Well 23 CC and $C D$ & 110 & 320 \\
\hline & Yiftahel & Structure 700 conflagration date & 135 & 240 \\
\hline \multirow[t]{2}{*}{ In-site transition } & Abu Hureyra & AbuH 2 A-B Transition & 160 & 290 \\
\hline & Ayn Abū Nukhalya & Phase 1 to 3 Boundary & 195 & 585 \\
\hline
\end{tabular}




\begin{tabular}{|c|c|c|c|c|}
\hline & \multirow[t]{6}{*}{ Ain Ghazal } & MPPNB-1-2 transition Boundary & 215 & 360 \\
\hline & & MPPNB-2-3 transition Boundary & 250 & 380 \\
\hline & & MPPNB-3-4 transition Boundary & 225 & 385 \\
\hline & & $\begin{array}{l}\text { Ain Gazal } 14 C M-P P N B \text { end } \\
\text { Sigma_Boundary }\end{array}$ & 370 & 650 \\
\hline & & $\begin{array}{l}\text { Ain Gazal 14C L-PPNB onset } \\
\text { Sigma_Boundary }\end{array}$ & 110 & 225 \\
\hline & & $\angle P P N B-P P N C 14 C$ transit Boundary & 130 & 280 \\
\hline & \multirow[t]{2}{*}{ Beidha } & Boundary End Beidha A & 175 & 405 \\
\hline & & Boundary Onset Beidha B & 200 & 490 \\
\hline & Khirokitia & Khirokitia Ouest onset Boundary & 210 & 460 \\
\hline & \multirow[t]{4}{*}{$\begin{array}{l}\text { Parekklisha- } \\
\text { Shillourokambos }\end{array}$} & Ancienne A-B Boundary & 150 & 310 \\
\hline & & Ancienne B-C Boundary & 140 & 315 \\
\hline & & Ancienne C-Moyenne Boundary & 130 & 345 \\
\hline & & Moyenne-Recente Boundary & 220 & 405 \\
\hline \multirow[t]{5}{*}{ Activity duration } & \multirow[t]{5}{*}{ 'Ain Ghazal } & Span MPPNB-1 & 60 & 185 \\
\hline & & Span MPPNB-2 & 225 & 400 \\
\hline & & Span MPPNB-3 & 30 & 130 \\
\hline & & Span LPPNB & 275 & 515 \\
\hline & & Span PPNC & 165 & 325 \\
\hline
\end{tabular}

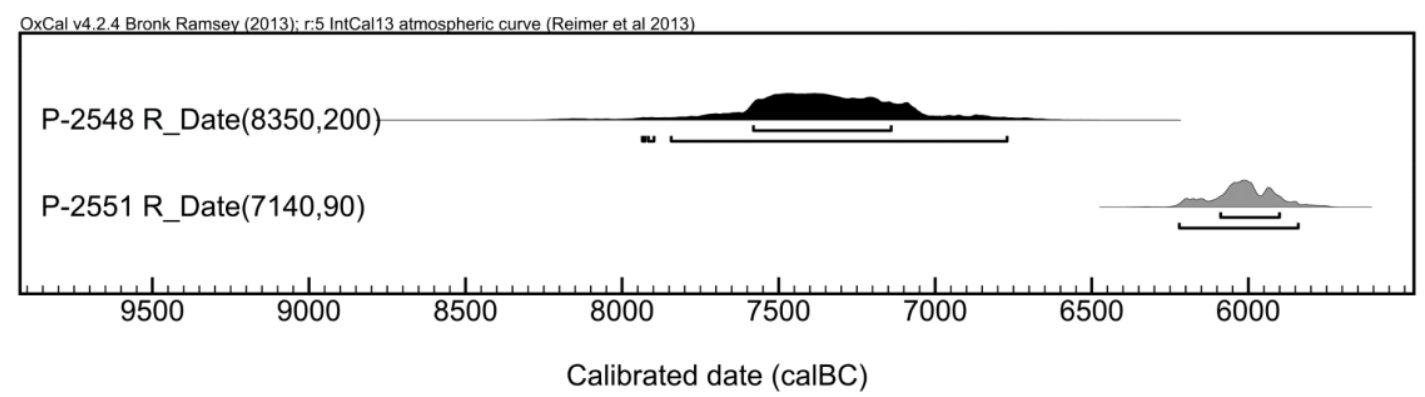

Figure 1. Radiocarbon samples P-2548 and P-2551 from Kalavassos-Tenta. Both of these samples originate in the same context, but sample P-2551 was not subject to a complete 
acid-alkali-acid procedure, suggesting that the apparent age discrepancy stems from insufficient pretreatment.
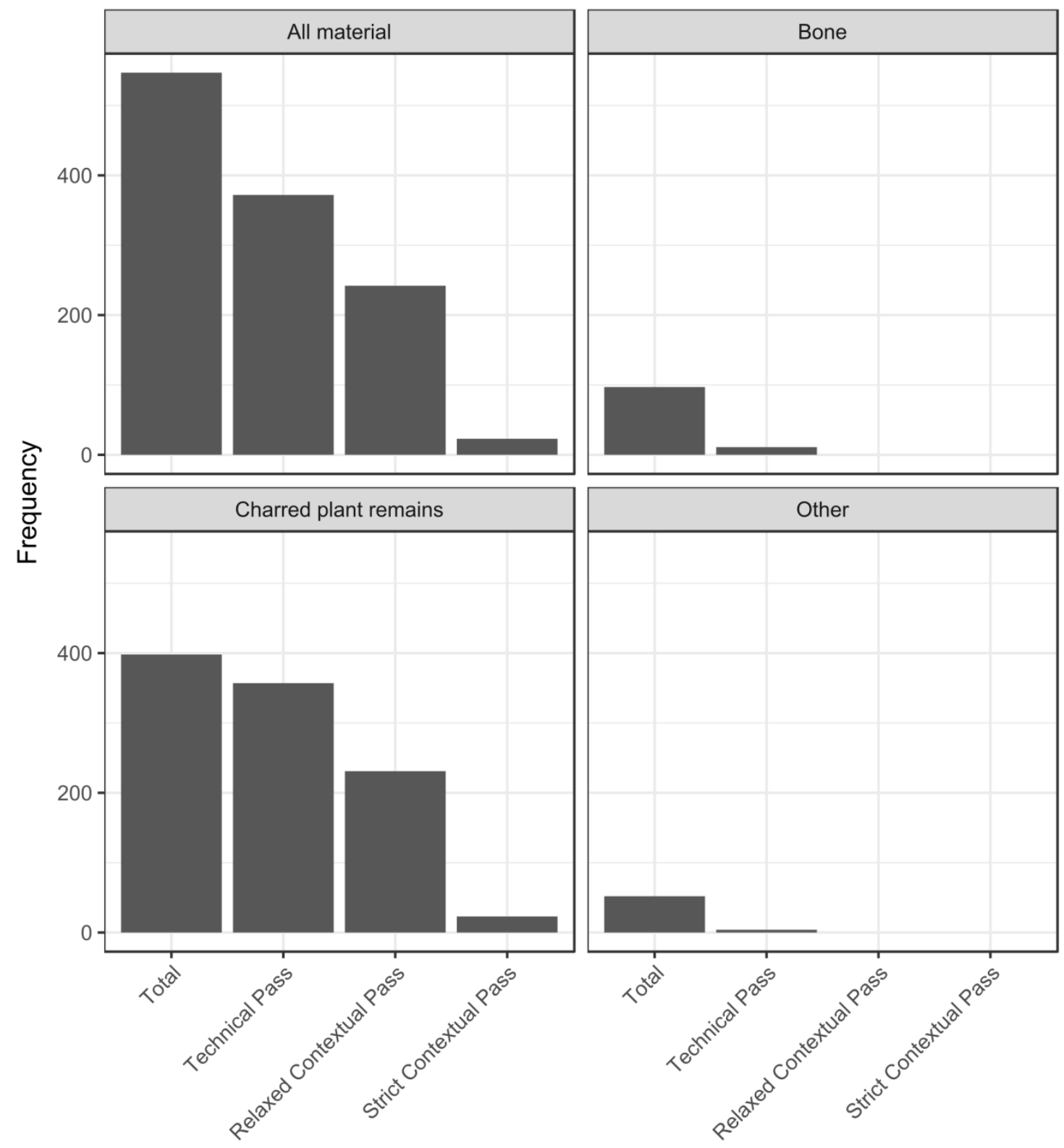

Figure 2. Summary of assessment results under relaxed contextual criteria. 


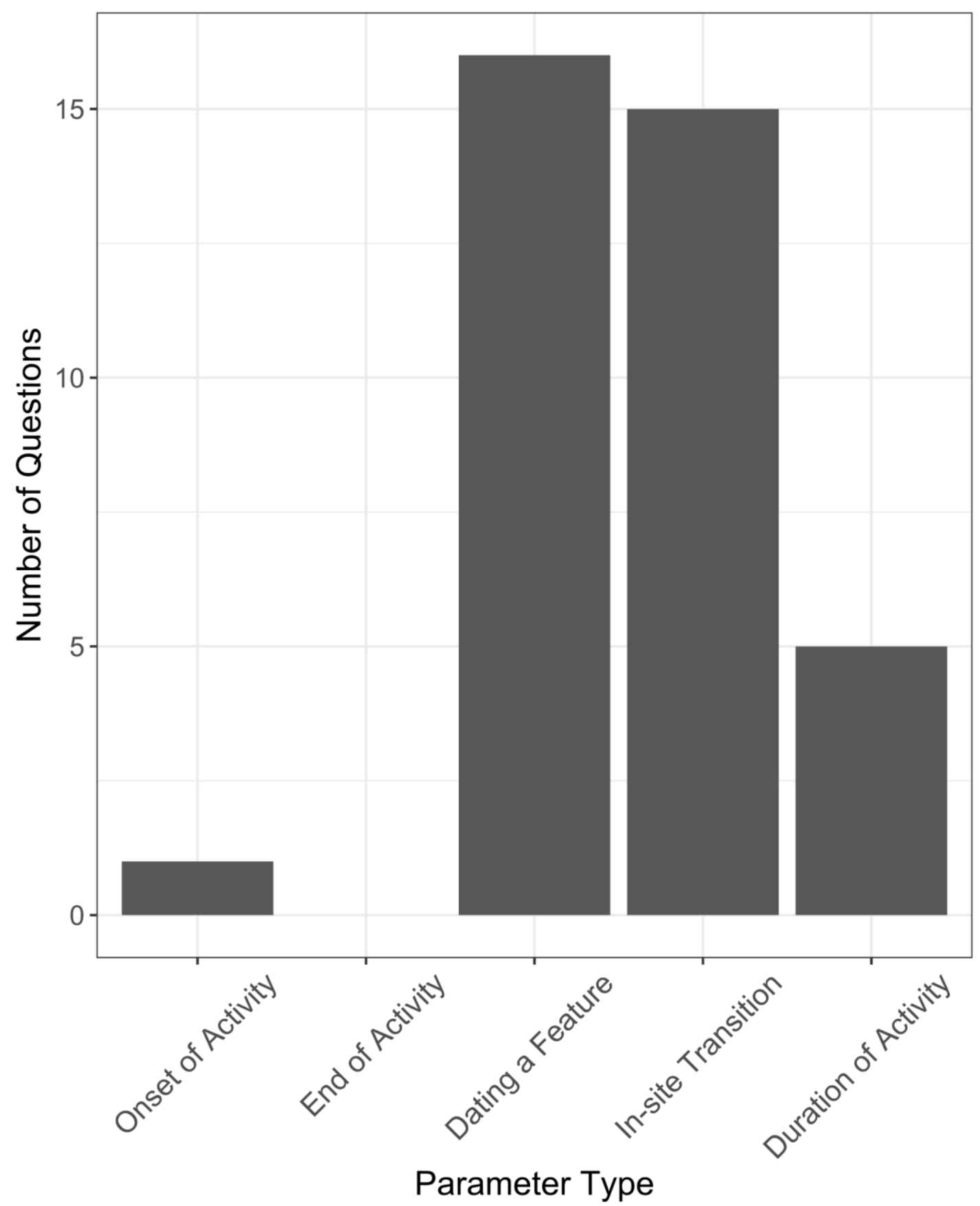

Figure 3 Types of questions asked in the modelling study and their frequencies. 


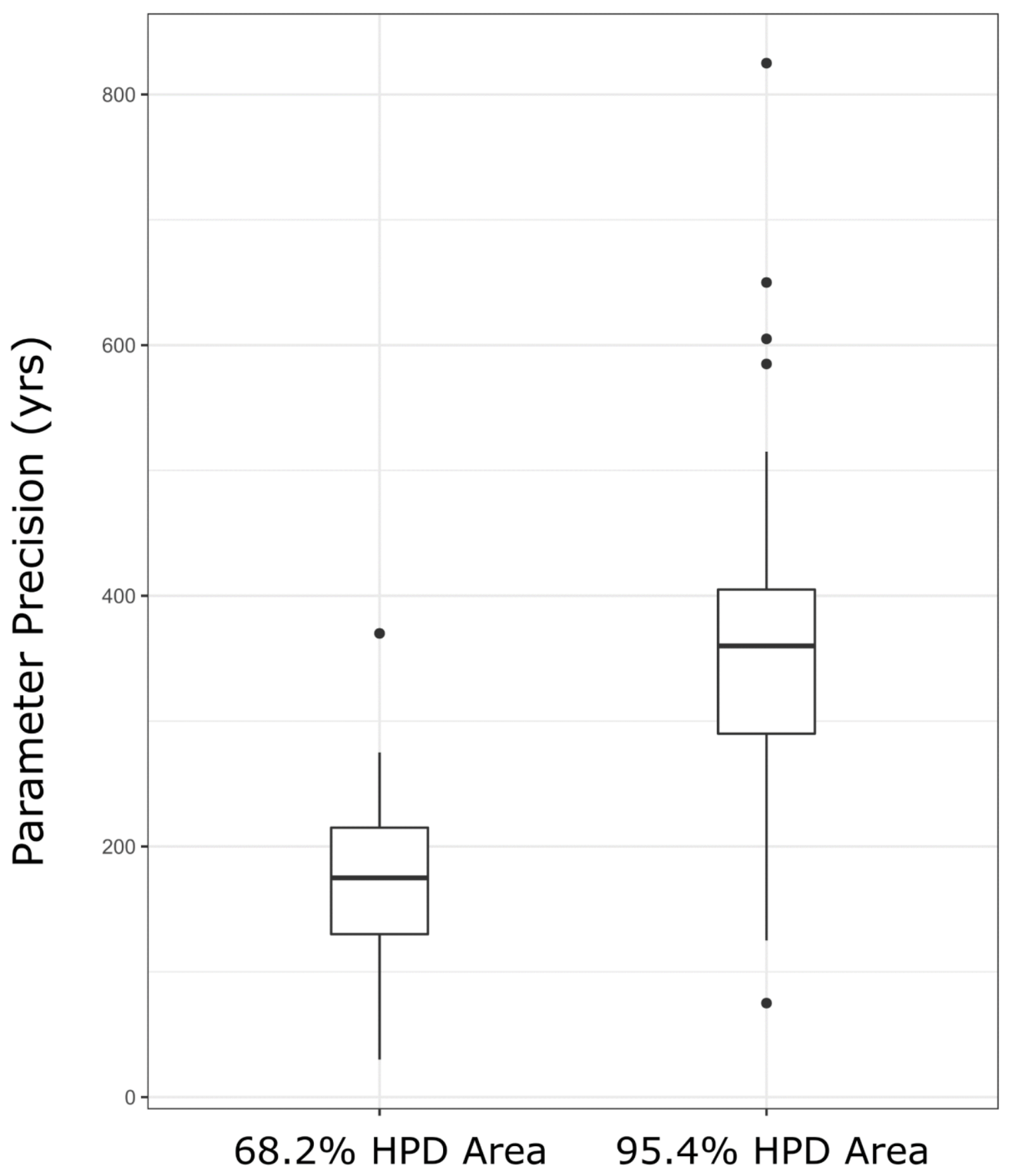

Figure 4 Boxplots summarizing the precision of the results of the modelling study in terms of parameter precision. 

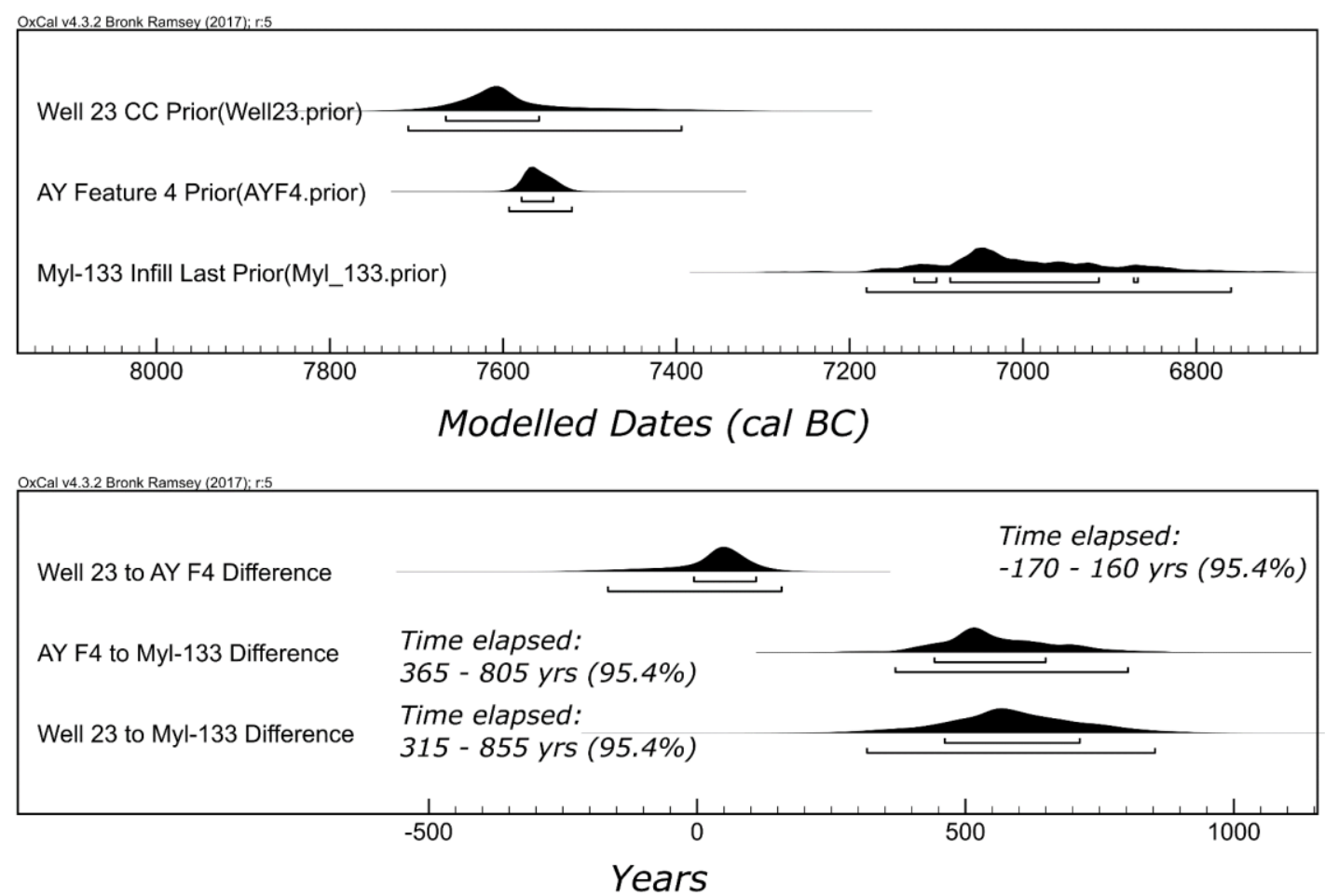

Figure 5. Top: comparison of estimated dates for the burial layer in Well 23 at

Shillourokambos, Feature 4 at Ais Yiorkis and the infill of Well 133 at Mylouthkia. Bottom: estimates of the time elapsed between these three features.

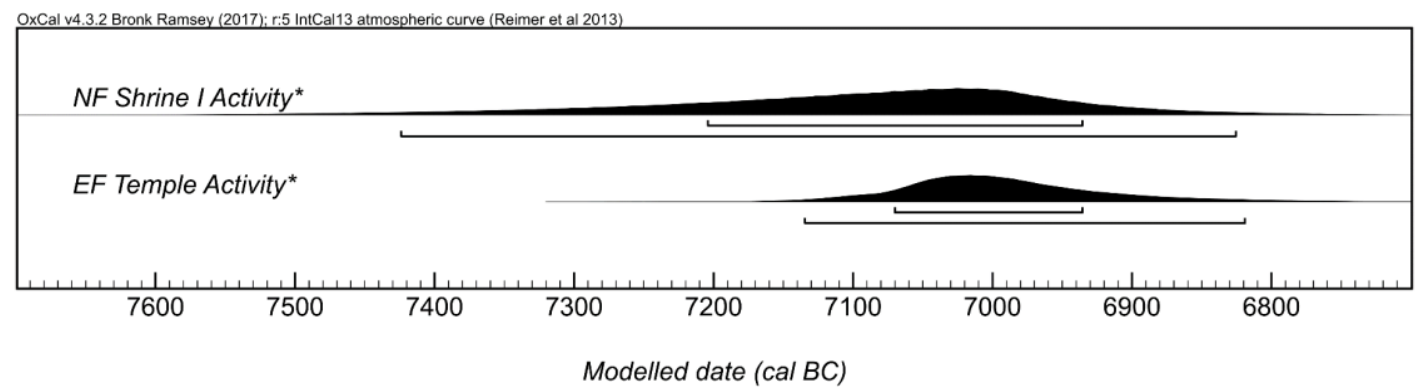

Figure 6 Modelled date ranges for the two structures from 'Ain Ghazal. 